NBER WORKING PAPER SERIES

\title{
THE IMPACT OF NEW DEAL EXPENDITURES ON LOCAL ECONOMIC ACTIVITY: AN EXAMINATION OF RETAIL SALES, 1929-1939
}

\author{
Price V. Fishback \\ William C. Horrace \\ Shawn Kantor \\ Working Paper 8108 \\ http://www.nber.org/papers/w8108 \\ NATIONAL BUREAU OF ECONOMIC RESEARCH \\ 1050 Massachusetts Avenue \\ Cambridge, MA 02138 \\ February 2001
}

The authors are deeply indebted to Larry Neal and Joseph Mason who facilitated the collection of the New Deal data used in the paper. We would also like to thank Stanley Engerman, Michael Haines, Daniel Houser, Harry Kelejian, Robert Margo, Ronald Oaxaca, and John Wallis for their comments and suggestions for improving the manuscript. University seminar participants at Arizona, California-Los Angeles, Dartmouth, Emory, Florida State, George Mason, Kentucky, Miami (Ohio), Rutgers, Virginia, Virginia Tech, Williams, and the audiences at the Third World Cliometrics Congress, the conference in honor of Lance Davis, and the NBER group on the Development of the American Economy have provided valuable advice. Kari Beardsley, Amanda Ebel, Michael Hunter, Angela Phillips, Ruthanna Ruffer, and Jeffrey Taylor did excellent work in computerizing the data. Financial support has been provided by National Science Foundation Grants SBR9708098 and SES-0080324, the Earhart Foundation, the University of Arizona Foundation, and the University of Arizona Office of the Vice President for Research. Please do not cite without the authors' permission. The views expressed herein are those of the authors and not necessarily those of the National Bureau of Economic Research.

(C) 2001 by Price V. Fishback, William C. Horrace and Shawn Kantor. All rights reserved. Short sections of text, not to exceed two paragraphs, may be quoted without explicit permission provided that full credit, including (C) notice, is given to the source. 
The Impact of New Deal Expenditures on Local Economic Activity:

An Examination of Retail Sales, 1929-1939

Price V. Fishback, William C. Horrace and Shawn Kantor

NBER Working Paper No. 8108

February 2001

JEL No. E62, H53, N42, R11

\begin{abstract}
This paper empirically examines the New Deal's impact on local economic activity, as measured by retail sales, during the 1930s. Using a recently-uncovered data set that describes over 30 federal New Deal spending, loan, and mortgage insurance programs across all U.S. counties from 1933 to 1939, we estimate how the various New Deal programs that were designed to accomplish different objectives influenced retail spending. Our empirical approach accounts for both the simultaneity between New Deal allocations and economic activity and the geographic spillovers that likely resulted when spending in one county may have affected the economies of its neighbors. We find that New Deal spending on public works tended to promote retail sales in both the county where the money was spent and in contiguous neighbors, while spending on work relief increased economic activity in the county where the money was spent but at the expense of neighboring counties. Agricultural spending that limited production was associated with lower retail spending. New Deal loan programs appear to have had little or a somewhat negative effect. Finally, increases in the value of mortgages insured by the Federal Housing Administration had a strong positive effect on local economic growth during the Depression.
\end{abstract}

Price V. Fishback Department of Economics McClelland Hall 401 University of Arizona

Tucson, AZ 85721

and NBER

(520) 621-4421

pfishback@bpa.arizona.edu
William C. Horrace Department of Economics McClelland Hall 401 University of Arizona Tucson, AZ 85721 and NBER (520) 621-6230 whorrace@u.arizona.edu
Shawn Kantor

Department of Economics

McClelland Hall 401

University of Arizona

Tucson, AZ 85721

and NBER

(520) 621-6226

skantor@u.arizona.edu 


\section{Did New Deal Grant Programs Stimulate Local Economies? A Study of Federal Grants and Retail Sales During the Great Depression}

The New Deal launched the most dramatic peace-time expansion of the federal government in U.S. history. The Roosevelt administration launched a myriad of new federal programs, including regulations and federal mandates, social insurance programs, and an unprecedented amount of new federal spending. Annual federal outlays outside of the traditional categories of national security and international affairs were four to six times higher in the 1930s than in 1929 (U.S. Census Bureau 1975, 1115, series Y471). In response to the Great Depression, the Roosevelt administration funded a variety of different programs on an unprecedented scale in an attempt to revive economic activity. The Public Works Administration (PWA) handed out grants to build civil infrastructure, while the Federal Emergency Relief Administration (FERA), the Civil Works Administration (CWA), and the Works Progress Administration (WPA) granted state and local governments funds to provide work relief and direct relief and to build and maintain infrastructure. The New Deal launched the farm programs that paid farmers to alter their land usage. New Deal agencies loaned funds to state and local governments, banks, homeowners, farmers, and to industry in order to provide needed liquidity. Through the Federal Housing Administration (FHA) the federal government sought to prop up the housing sector by insuring home improvement and mortgage loans.

Popular histories often portray the New Deal as a successful antidote to the Great Depression. ${ }^{1}$

The New Deal, however, was an amalgam of numerous multifaceted programs that sometimes worked at cross purposes. Studies of New Deal macroeconomic policy suggest New Deal spending had a limited role in the recovery. ${ }^{2}$ Harold Cole and Lee Ohanian (forthcoming) argue that the policies of the National Industrial Recovery Act designed to raise prices and wages and to weaken antitrust enforcement likely contributed to higher unemployment and slowed the economy's ability to achieve its long-term growth rate. Furthermore, Robert Higgs (1997) emphasized that the rapid introduction of New Deal policies and the continuous changes that followed created uncertainty that slowed private investment. Various studies of the impact of work relief programs have painted a mixed picture of their success in reducing 
unemployment. ${ }^{3}$ Finally, a growing literature on the political economy of New Deal spending suggests that political, as well as economic, concerns determined how New Deal funds were distributed across the U.S. ${ }^{4}$

Since the New Deal involved such a variety of different programs, some long-lived and others short-term and experimental in nature, it is no surprise that recent research offers conflicting views of the New Deal's effectiveness. An analysis that takes into account the simultaneous impacts of the multiple programs, therefore, can provide a better sense of the overall impact of the New Deal. In this paper we focus on the centerpieces of the New Deal relief and recovery programs: the federal grants that provided work relief and that led to the construction of public works; and the payments to farmers through the Agricultural Adjustment Administration (AAA). The programs accounted for sixty percent of federal New Deal spending during the period and, politically, these programs had the most direct impact on voters. Relief and public works spending had many broad similarities in that the grants typically were used to provide the unemployed with jobs on a range of public works projects. Even today, there are reminders of these New Deal programs in the form of public buildings, dams, roads, and other facilities that are still in operation. In contrast, the AAA grant payments were specifically designed to pay farmers to take land out of production. Thus, the net effects of AAA spending were likely to be quite different from those of relief and public works spending.

From a variety of perspectives, the New Deal offers a unique opportunity to learn how federal expenditures can influence local economies. The New Deal represented the beginning of the federal government's direct attempts to stimulate local economies, there was substantial geographic variation in how New Deal grants were distributed, and there were great differences in the paces of recovery across the United States during the course of the Great Depression. To measure the economic impact of these programs, we have constructed a data set that measures federal spending on public works and relief and agriculture in over 3,000 counties from 1933 to 1939 . We then examine how the programs influenced a general measure of economic activity - retail sales. Retail sales serve as a strong proxy for personal consumption of durable and nondurable goods, which has been considered a key variable in 
understanding the Great Depression (see Temin 1976, Romer 1990). The impact of the New Deal was likely to show up relatively quickly in the retail sector because the money going to relief workers and the needy was probably used to purchase immediate needs, such as food, clothing, and other merchandise.

In the next two sections we give a sense of the variation across counties in the changes in per capita retail sales during the 1930s and in the distribution of New Deal grants. We then use this variation to estimate the relationship between the growth rate of per capita retail sales and New Deal spending, while controlling for a variety of other factors that have been found to be important in cross-sectional studies of income growth. Given that New Deal funds were likely distributed in response to the economic situation in each county, we use instrumental variables to control for potential endogeneity. The results suggest that the two major categories of New Deal grants had quite different effects on local economies. Increases in public works and relief grants contributed to significant increases in retail sales. Meanwhile, AAA grants may have aided the farmers who received them, but, by drawing farmland out of production, may have lowered the incomes of farm workers. The net effect may have been to slow the pace of economic recovery in these agricultural communities.

\section{A Brief Overview of the Geographic Variation in the Great Depression}

In this paper we use per capita retail sales as our proxy for local economic activity. ${ }^{5}$ New Deal administrators used retail sales as one of their key measures of the health of local economies, in part because many of the modern indices of economic activity, such as unemployment rates and personal income, were unavailable during the 1930 s. $^{6}$ For our purposes retail sales has the added advantage of accounting for a major component of consumption and the data were reported for every county in the U.S. in $1929,1933,1935$, and 1939 . Retail sales is clearly an important measure of macroeconomic activity because even today the U.S. Bureau of Economic Analysis uses retail sales figures to create annual estimates of personal consumption of durable and nondurable goods for the National Income and Product Accounts (U.S. Bureau of Economic Analysis 1987, 11). Retail sales also are strongly related to personal 
income in cross-sectional comparisons across states. Correlations of state-level per capita personal income and retail sales for the years $1929,1933,1935$, and 1939 are $.87, .89, .88$, and .90 , respectively.

The 1930s was a decade of lost output for the economy as a whole, but there was substantial variation in the experiences across individual counties. By 1933 both real per capita GDP and per capita retail sales had fallen to approximately two-thirds of their 1929 peaks. In per capita terms real retail sales returned to its pre-Depression level by 1939, while real GDP returned to its 1929 level by $1940 .^{7}$ The national aggregate data disguise much of the variation across the United States. The ratio of 1939 retail sales to 1929 retail sales at the state level ranged from a low of 77 percent in Mississippi to a high of nearly 125 percent in South Carolina. The New England states appear to have had the most success in recovering to their pre-Depression levels as every state had higher real retail sales in 1939 than in 1929. Within many states there was substantially more variation than there was across the states. Table 1 contains information on the distribution of the ratio of 1939 to 1929 retail sales across counties within each state. Texas counties experienced some of the greatest variation as the discovery of new oil fields led to an explosion of economic activity in some counties, while the Dust Bowl and its aftermath contributed to a continuation of the Depression in some agricultural counties.

\section{New Deal Grants}

The crisis of the Great Depression led the Roosevelt administration to distribute unprecedented amounts of federal money in the form of nonrepayable grants. The federal government distributed $\$ 16.5$ billion in nonrepayable grants over the six-year period. The grants represented a new role for the federal government during peacetime, as the New Deal increased the federal government's outlays as a share of GDP from about 4 to 8 percent. Furthermore, the federal government began spending large amounts of money where it had spent very little before, setting the stage for a long-term structural shift in the

financial responsibilities of the national, state, and local governments. ${ }^{8}$ As a share of government expenditures at all levels, the New Deal raised the proportion of federal spending from 30 percent in 1932 to 46 percent by 1940 (Wallis $1984,141-42$ ). 
In 1940 the U.S. Office of Government Reports (OGR) produced county-level statistics on federal spending on over 30 New Deal programs for the period March 3, 1933, through July 30, 1939. ${ }^{9}$ We divide the nonrepayable New Deal grants into two distinct categories that potentially had quite different impacts on the economy: public works and relief grants; and Agricultural Adjustment Administration benefits paid to farmers. ${ }^{10}$ We group public works and relief grants together because the programs had broadly similar goals of hiring workers to build various public works projects and to provide other public services. Relief grants were primarily distributed under the aegis of the Works Progress Administration (WPA), the Federal Emergency Relief Administration (FERA), the Civil Works Administration (CWA), and the Social Security Administration's Aid to the Blind, Aid to Dependent Children, and Old-Age Assistance programs. The principal goal of these programs was to provide immediate relief to the unemployed and low-income people, as 85 percent of the grants were used to hire the unemployed on work relief jobs. These relief jobs ranged from make-work activities to maintenance activities to the building of sidewalks, post offices, schools, local roads, and other additions to local infrastructure. The public works grants included expenditures by the Public Works Administration (PWA), Public Buildings Administration (PBA), and the Public Roads Administration (PRA). These grants were also used largely to employ workers, but the programs were administered differently as they focused less on hiring people from the relief rolls and, thus, were able to employ a broader class of skilled workers. The public works programs also focused more on building large-scale projects like dams, roads, schools, sanitation facilities, and other forms of civil infrastructure (Clarke 1996, 62-68; Schlesinger 1958, 263-96).

The federal New Deal expenditures that provided the primary aid to the farm sector came through the AAA's payments to farmers to remove land from production. The impact of the AAA grants on retail sales was likely smaller than the impact of the relief grants and potentially even negative. On the one hand, farm owners might have received higher net incomes from the AAA program. Payments typically exceeded the income farmers would have earned on the land that they took out of production because the least productive land was removed first. If the AAA succeeded in raising farm prices, the farmers also 
would have earned more on the crops they produced. In addition, the higher prices and the limits on land usage would have encouraged farmers to raise yields on the land they kept under cultivation. On the other hand, the AAA might well have had an adverse effect on the incomes of farm laborers, tenants, and sharecroppers. There is evidence that sharecroppers and tenants did not receive their full share of the AAA payments on the lands that they had cultivated and that some were demoted to wage laborers (Whatley 1983, Biles 1994, 39-43; Saloutos 1974). Further, the AAA payments required that the farmer remove land from production. Consequently, the demand for farm labor likely fell, leading to declines in laborers' incomes (Alston 1981). Thus, the ultimate impact of the AAA on retail sales in a county depended on whether the increased spending by the actual recipients of the payments was offset by the reduced spending of farm workers, tenants, and sharecroppers.

Table 2 shows the variation in state averages for the major grant categories, as well as summary statistics for the variation within states. As was the case with the recovery in retail sales, there was substantial variation in the extent of per capita New Deal spending across the country. The patterns of New Deal spending across states and within states differed for the two broad categories. Spending on relief and public works was over $\$ 125$ per person in the heavily urbanized states in the Northeast and Midwest and was well over \$200 per person in many western states. Meanwhile, relief and public works expenditures were below $\$ 80$ per person in many southern states. AAA expenditures were highest in agricultural regions, particularly the West North Central region and the Mountain West. The South received substantially higher amounts per capita than did the Northeast, but much less than the amounts spent in the West and the West North Central.

\section{Summarizing the Impact of New Deal Grants on Retail Sales}

Using the cross-sectional variation in retail sales growth and New Deal spending across U.S. counties, our objective in the paper is to estimate an empirical growth model that produces reduced-form estimates of the impact of New Deal grants on local economic activity. Our empirical model controls for a variety of factors that would have influenced economic growth and retail expenditure patterns. The 
reduced-form estimate will be an amalgam of a series of interactions between New Deal grants, a variety of forms of private spending and production, income, and ultimately retail consumption. ${ }^{11}$

Models of fiscal federalism suggest federal grants may influence local income and, hence, retail sales in a number of ways. First, regional models show that an additional dollar in grants raises local income relatively more as the share of after-tax income spent on goods and services produced within the county rises. Second, the marginal grant expenditure will have a relatively smaller effect if the spending crowds-out private activity. The AAA explicitly involved a significant degree of crowding-out because it required farmers to remove land from production in a national effort to raise farm prices. The crowdingout caused by the public works and relief programs was likely to be more subtle. Given that there was such high unemployment in the 1930s, the public works and relief grants might have succeeded in providing temporary employment and relief for those who had no private opportunities. Therefore, we might expect the crowding-out effect to have been rather modest. The existing evidence offers a mixed picture, however. Wallis and Benjamin (1989) find evidence that an additional relief job led to a one-half job reduction in the private sector. Administration officials argued that they sought to avoid such crowding by setting monthly relief wages at relatively low levels. Robert Margo (1993) found, however, that workers stayed on relief jobs for extended periods and concluded that risk-averse workers might have preferred the stability of relief jobs with lower pay to the risk of taking a higher-paying private sector job with uncertain longevity. As a result, WPA officials sought to encourage relief workers to take private sector employment by guaranteeing that they would be rehired by the WPA if they lost their private sector jobs. Finally, Robert Fleck (1999b) studied the impact of relief employment on measured unemployment, which included those employed on relief jobs, and found that an additional relief job raised the measure of unemployment by an additional person or more. Fleck speculated, however, that the increased measure of unemployment might not have necessarily represented diminished private employment opportunities because the higher unemployment might have been a discouraged worker who re-entered the labor force in order to claim relief benefits. 
Third, New Deal spending might have raised the productivity of local producers if it was devoted to building infrastructure that cut transport costs to other areas and thus raised the net price that local sellers received. Cuts in production costs from New Deal infrastructure potentially had either positive or negative effects on local incomes based on the extent to which the public capital enhancements either substituted for or complemented labor. ${ }^{12}$

Fourth, the impact of federal grants might have been enhanced if they stimulated additional state and local spending on projects that would not have been built otherwise. The overall impact of this response was probably small because state and local governments faced significant legal restrictions in their ability to run deficits during the 1930s, so changes in state and local government spending were likely to be matched by offsetting changes in taxes. On the other hand, to the extent that state and local governments reduced their own spending on public works as the federal government implemented fresh spending under the New Deal, the measurable impact of the federal grants would be small. ${ }^{13}$

Finally, New Deal grants may have created a fiscal drag if higher resulting incomes from the New Deal grants caused people to pay higher income taxes or encouraged them to purchase goods subject to excise taxes. Federal income and excise tax rates were uniform across the country and the size of this effect was not likely to be large because fewer than 7 percent of households were paying income taxes during the 1930s.

Given the lack of income data at the county level during the 1930s, we develop our empirical model to estimate the impact of New Deal grants on retail sales growth instead. The ratio of retail sales to personal income at the national level was approximately 0.53 , so if we were to find that an additional dollar of New Deal grants raised retail spending by 53 cents, we might conclude that income in the county rose by roughly a dollar. ${ }^{14}$ Of course, this is a rough estimate based on the average and the marginal effect could be higher or lower. Therefore, in our discussions of the results, we focus more attention on how a one-standard-deviation increase in New Deal spending might have affected the retail sales growth rate. 


\section{Data Considerations}

The precision of our estimates of the impact of New Deal grants on retail sales is constrained in part by the availability of data. The Census Bureau first began collecting annual retail sales information for each county in the United States in 1929 and performed retail censuses for the years 1933, 1935, and 1939. The OGR reported data on spending in each U.S. county for the whole period between March 3, 1933, and June 30, 1939, for each of about 30 New Deal programs. The timing of the introduction of the New Deal meant that nearly all of the spending started in July 1933. Census information on other correlates of economic activity is available for 1930 and 1940. For more details on precise sources, see the Appendix 1.

The bulk of our analysis focuses on the growth rate of per capita retail sales from 1929 to 1939 as a function of New Deal spending between March 1933 and June 1939. This focus enables us to examine the extent to which the New Deal promoted a return to the peak economic levels of 1929. More importantly, using 1929 as a base period is beneficial because there was no New Deal spending of any kind then, so the measurement of the New Deal's "treatment effect" will be more accurate. Using 1933 as a starting point for measuring the growth rate, on the other hand, would be more problematic because there was roughly a half year of New Deal spending during 1933. Since our county-level data do not provide a precise breakdown of New Deal spending in each year, we will have more measurement error in determining the amount of New Deal spending that took place in 1933 versus 1934 to 1939.

As robustness checks on our estimates of the New Deal's impact on growth rates during the 1930s, we also examine the sub-periods 1929 to 1935 and 1933 to 1939. These estimates provide alternative perspectives on the New Deal, but both are subject to more measurement error than the 1929 to 1939 growth rate estimates. The 1929 to 1935 growth-rate estimations capture the short-run effects of the First New Deal (1933-1935). However, we need to be careful in interpreting these results because our measures of New Deal spending through 1935 depend upon our assumptions about how to split the aggregate county-level New Deal data into pre- and post-1935 spending. Even though the OGR reported aggregate New Deal expenditures from 1933 to 1939 for each program, some programs had distinct 
beginning and end points that enable us to estimate the extent of spending through June 1935. The AAA Rental and Benefit payments ended in 1935 and the primary relief programs of the First New Deal, the CWA and the FERA, had ended by June 1935. Therefore, we have reasonably accurate pictures of the first two fiscal years of New Deal spending. Dividing public works spending into the First and Second New Deal periods is somewhat harder because the PWA, PBA, and PRA spanned the entire New Deal. We use annual state-level information, however, to split each county's overall public works spending into the various years based upon the annual spending flows within its state. ${ }^{15}$

The analysis of retail sales growth rate from 1933 to 1939 allows us to measure the impact of the New Deal from trough to recovery. We again face more measurement error here than in the 1929 to 1939 analysis because of our inability to precisely delineate spending in 1933. The starting date for the aggregate county data is March 1933, although nearly all of the spending occurred after July 1933. If the distribution of New Deal grant spending in 1933 was the same as in later years, then the New Deal spending from the end of 1933 through 1939 would be some percentage of the total New Deal spending for the entire period. To the extent that the actual spending in each county during the last 6 months of 1933 did not follow the same pattern as in the later years, measurement error will result.

\section{The Estimation Procedure}

A large and growing literature examines the determinants of cross-sectional variation in economic growth rates across geographic areas. ${ }^{16}$ The typical growth model empirically estimates the growth rate as a function of the prior level of the variable of interest and a series of structural features of the economy at the starting point of the period under consideration. Our analysis is complicated by the fact that we are interested in the impact of New Deal grant spending, which itself may have been determined by the growth rate that we are trying to explain. Therefore, we seek to find means of reducing the endogeneity bias of the New Deal variables' impacts by estimating the following set of equations: 


$$
\begin{aligned}
& g_{i 29-39}=\beta_{1} \mathrm{NDPR}_{\mathrm{i} 33-39}+\beta_{2} \mathrm{NDA}_{\mathrm{i} 33-39}+\beta_{3} \mathrm{R}_{\mathrm{i} 29}+\beta_{4} \mathrm{Z}_{\mathrm{i} 29}+\beta_{5} \mathrm{~S}+\varepsilon_{\mathrm{i}} \\
& \mathrm{NDPR}_{\mathrm{i} 33-39}=\theta_{1} \mathrm{INST}_{\mathrm{i}}+\theta_{2} \mathrm{R}_{\mathrm{i} 29}+\theta_{3} \mathrm{Z}_{\mathrm{i} 29}+\theta_{4} \mathrm{~S}+v_{\mathrm{i}} \\
& \mathrm{NDA}_{\mathrm{i} 33-39}=\gamma_{1} \mathrm{INST}_{\mathrm{i}}+\gamma_{2} \mathrm{R}_{\mathrm{i} 29}+\gamma_{3} \mathrm{Z}_{\mathrm{i} 29}+\gamma_{4} \mathrm{~S}+\xi_{\mathrm{i}}
\end{aligned}
$$

where $\mathrm{g}_{\mathrm{i} 29-39}$ is the growth rate in per capita retail sales from 1929 to 1939 in county $\mathrm{i}, \mathrm{NDPR}_{\mathrm{i} 33-39}$ is per capita New Deal public works and relief grants from March 1933 through June 1939, $\mathrm{NDA}_{\mathrm{i} 33-39}$ is per capita New Deal AAA grants, and $\mathrm{R}_{\mathrm{i} 29}$ is per capita retail sales in 1929. We control for the initial level of retail sales because counties with relatively lower starting levels will tend to have greater growth rates because of their small initial values. $Z_{\mathrm{i} 29}$ is a vector of structural correlates, measured in 1929 or 1930 , that might have determined the growth in economic activity over the decade; $\mathrm{S}$ is a vector of state dummy variables; and $\mathrm{INST}_{\mathrm{i}}$ is a vector of instrumental variables that were selected because they are correlated with the New Deal grants but uncorrelated with the error term, $\varepsilon_{\mathrm{i}}$, of the growth equation. The error terms in the equations, $\varepsilon_{\mathrm{i}}, v_{\mathrm{i}}$, and $\xi_{\mathrm{i}}$, are assumed to be independent and identically distributed and uncorrelated with each other.

The growth in retail sales over the 1930s is interesting in its own right, but we use the measure as a proxy for changes in the overall economic activity in a county. Therefore, our empirical model includes variables that not only may have effected changes in retail consumption, but also would have produced changes in per capita income. The regression coefficients, therefore, will represent an amalgam of the variables' effects on income growth and their impacts on retail consumption. A primary reason for including these control variables is to avoid problems of omitted variables bias that might lead to improper inferences about the impact of New Deal spending on the growth rates. Numerous crosssectional studies show that incomes and the growth in incomes are influenced by a wide range of factors that include the race and ethnicity of the population, their education level, the age distribution, the extent of urbanization, and the structure of the economy. These factors capture the variations in skill levels, life cycle consideration, and the nature of opportunities for earning income (including the extent of discrimination). Holding income constant, the racial and ethnic composition of the population, education, 
age, and urbanization also tend to influence consumption patterns and, thus, are likely to influence the share of income spent on retail goods.

Recent studies have also begun to explore the impact of climate and geography on economic growth (Diamond 1997, Gallop, Sachs, and Mellinger 1999, Engerman and Sokoloff 2002, Acemoglu, Johnson, and Robinson 2002 and 2003, Rappaport and Sachs 2003). Our climate measures, all for the 1930s, include average monthly precipitation, average daily temperature, the number of months of extreme or severe drought, and the number of months of extreme and severe wetness. Since farm incomes are more likely to be influenced by weather, we have also interacted these variables with the percentage of the county's land in farms as of 1929. Our geography variables also include access to major rivers, the range in elevation within the county, the maximum elevation, access to coastlines along the Atlantic Ocean, Pacific Ocean, Gulf Coast, and the Great Lakes, and the presence of bays, lakes, swamps, and beaches.

We include a set of state dummy variables to capture unmeasured factors that were common to the counties in the states but varied across states. The state dummy variables might capture state policies and changes in state policies over the decade, differences in the cost of living across states, policies related to state taxation and spending, or state laws relating to retail stores. One example of a major policy change during the 1930s for which the state dummies would control is the introduction of income taxes and sales taxes in certain states.

We also seek to control for pre-existing trends in economic activity. The Census did not begin surveying retail establishments until 1929, so we are unable to establish the trends in retail sales during an earlier period. As an alternative approach, we have included the growth rate in population between 1920 and 1930. Population growth from 1930 to 1940 has a .33 correlation with per capita retail sales growth from 1929 to 1939; therefore, population growth might be a reasonable proxy for retail sales growth in the earlier period. ${ }^{17}$

Because New Deal funds were not distributed randomly, but in response to economic crises across the country, there is the possibility that the OLS coefficients of the New Deal's effect will be 
biased. New Deal administrators stated that their objectives in distributing relief funds and, to some extent, the public works funds were to provide jobs for the unemployed, to offset economic distress, and to promote economic recovery. The explicit goal of the AAA program was to raise farmers' incomes, although landowners in particular tended to be the disproportionate beneficiaries. The empirical literature on the geographic distribution of programmatic New Deal spending at the county level suggests that relief spending was distributed to areas where there was relatively more economic distress, while the public works programs responded to higher unemployment (see Fishback, Kantor, and Wallis 2003). Meanwhile, the AAA was distributed to areas where there was a greater downturn in retail sales. The potential simultaneous relationship between the economic downturn and increased New Deal spending suggests that the OLS estimates of the causal relationship between retail sales growth and New Deal spending would be biased downward.

The empirical literature on the distribution of New Deal funds has identified a number of political and geographic variables that were important determinants of the spending. Since these factors might well have been uncorrelated with the growth in economic activity during the 1930s, it gives us the opportunity to use an instrumental variables approach to correct the endogeneity bias. Robert Fleck (1999b) followed a similar strategy in developing instruments for a county-level analysis of the impact of relief jobs and spending on measured unemployment.

The instrumental variables procedure requires that we find variables that were correlated with New Deal spending but uncorrelated with the error term of the retail sales growth equation. We use four criteria in choosing appropriate instruments. First, the instrumental variables have to be important determinants of New Deal spending and not themselves influenced by the New Deal. All of the instruments we choose are from a time period prior to the 1930s or are geographic characteristics of the county so the New Deal could not have influenced the variables. Second, the instruments had to provide statistical explanatory power to at least one of the first-stage New Deal regressions. The statistical relevance of a variable was determined using a t-test of its coefficient, F-tests to determine the joint statistical significance of a group of variables, and Hahn-Hausman (2002) tests to examine the issue of 
weak instruments. Third, the instrument's coefficient had to have the expected sign in at least one of the first-stage regressions. We expect the instruments to make economic sense in the first-stage regression so that the second-stage results do not rely on spurious relationships from the first-stage estimation. Fourth, we used Hausman (1983, 433; also see Greene 2003, 413-14) specification tests to ensure that the set of instruments we considered did not show signs of correlation with the estimated error of the second-stage retail sales growth equation. If the Hausman test rejected the hypothesis that the instrument set was uncorrelated with the second-stage error term, it indicated that one or more of the instruments may have been inappropriately omitted from the retail sales equation.

The large literature on the political economy of New Deal spending highlights numerous candidates for identifying instruments. Robert Fleck (2001b) has suggested that a key determinant of aggregate New Deal spending at the state level was land area. Fleck, John Wallis (2001), and Fishback, Kantor, and Wallis (2003) have found land area to have influenced the distribution of spending in at least some programs. Spending on public roads, for example, followed a rule based on land area and population, so by construction the size of the state or county determined how much would be spent. Land area is a useful instrument because county boundaries were set prior to the New Deal and the grants themselves could not have influenced the physical size of the county.

Since Wright's (1974) analysis, scholars of the New Deal have focused on the political role of the spending. The Roosevelt administration may have distributed money to influence the likelihood of reelection in later years and/or to reward long-time supporters. Nearly all studies find that the administration distributed more funds to areas that tended to be more volatile in their support for Democrats (see Wright (1974), Wallis (1987, 1998), Fleck (2001a, 2001b, 1999b), and Fishback, Kantor, and Wallis (2003)). To measure the volatility (or, what Wright 1974 referred to as "flexibility") of Democratic support among county voters, we use the standard deviation of the percent voting for the Democratic presidential candidate from 1896 to 1928 . We use 1928 as the terminal year to avoid any correlation that might arise from using the 1932 election, which might have been influenced by changes in retail sales during the early 1930s. Furthermore, Fleck (1999b and 1999c) found that measures of voter 
turnout were important determinants of the distribution of FERA spending and relief jobs across counties. He used a measure of voter turnout in 1928 as an instrument when examining the impact of relief on county unemployment statistics. To reduce the potential for correlation with the error term in the secondstage retail sales growth equation, we also use a measure of voter turnout from 1928.

We also found that membership in church congregations in 1926 as a share of the population is an effective instrument. Church congregations were a major source of charitable activity and relief prior to the New Deal, so it is possible that religious organizations had the private means to alleviate economic distress during the Great Depression. ${ }^{18}$ Thus, New Deal relief administrators may have distributed fewer funds to areas with more parochial activity.

The final set of instruments relate to geographic location, as measured by the latitude and longitude of the county seat. We would expect these variables to be especially important for the distribution of AAA spending. Geography played a central role in the development of agriculture in the United States. Various features of farming, such as the timing of farm settlement, soil quality, technology and methods chosen, or crop choice, were strongly related to a county's geographic location (i.e., its latitude and longitude). Obviously, the geographic location of the county and its seat was established long before the 1930s, so New Deal policy could not have influenced latitude or longitude measures.

Choosing appropriate instruments to a large extent is a subjective endeavor. Asserting the lack of correlation between the second-stage error and the instrumental variable is sometimes controversial. We have followed three procedures to allay concerns that our instruments are inappropriate. First, we have performed extensive robustness testing by running the model with various combinations of instruments. Generally, the basic results of the analysis are unchanged by the exclusion or inclusion of any one of the instruments. However, if we remove enough of the instruments so that the remaining instruments become too weak to add to the explanatory power of the first-stage, the basic results we report below are weakened. Second, using the Hausman test mentioned above, we have tested the correlation between our best estimate of the second-stage error term and the group of instruments. The results of the test indicate that the set of identifying instruments are not correlated with the retail sales equation error and that the 
instruments as a group have not been inappropriately omitted from the retail sales growth equation. Finally, we performed a Hahn-Hausman test to ensure that the instruments are not weak and, thus, are adding statistically significant power to the first-stage estimation. ${ }^{19}$

\section{Empirical Results}

As a first step, we establish a baseline relationship between the growth rate in per capita retail sales and the level of per capita New Deal spending. The first four columns of Table 3 present OLS regression results of retail sales growth from 1929 to 1939 on the two forms of New Deal grants. To put the coefficients into context, we report the impact of a one-standard-deviation (OSD) increase in the New Deal grant variables in Table 4. An OSD change in the spending can give a good sense of how much of the cross-sectional variation in retail sales growth could be explained by differences in New Deal grants across the country. We also use the coefficients to estimate how much per capita retail sales in 1939 would have increased from its sample mean $(\$ 533.50,1967$ dollars $)$ if per capita New Deal spending rose by a dollar. Finally, the typical ratio of retail sales to personal income for the nation as a whole was approximately .53; therefore, a rough point estimate can be obtained for the impact on income by dividing by the estimated change in per capita retail sales by 0.53 .

The simple OLS regression shows that public works and relief spending had a positive effect on retail sales growth, while AAA grants had a negative effect. Both coefficients are statistically significant, but the public works and relief effect is quite small and explains very little of the differences in retail sales growth. The first line in Table 4 shows that an OSD change in per capita public works and relief spending was associated with a 0.05 standard deviation change in the growth rate. Increasing per capita spending on public works and relief by one dollar would have added 2 cents in per capita retail sales in 1939. Meanwhile, the AAA coefficient suggests that an OSD increase in AAA spending would have lowered retail sales growth by 0.27 standard deviation and an added dollar in per capita AAA spending would have reduced retail sales in 1939 by 14 cents. When we add the full list of correlates to the OLS analysis, the basic results do not change much. Table 4 shows that the OSD impact for the public works 
and relief variable is 0.03 and the coefficient is no longer statistically significant. The addition of correlates reduces the magnitude of the negative coefficient on the AAA, such that the OSD impact is -0.05 .

It is likely, of course, that the OLS measures of the impact of the New Deal are biased downward. When we control for the endogeneity of New Deal spending using the 2SLS procedure, the New Deal administrators' view that their public works and relief grants contributed to economic growth is rejuvenated. The AAA still has no positive effect, suggesting that the benefits of the payments to landowners were offset by the losses to farm workers when the amount of land in production was reduced.

Table 3 reports the 2SLS results for the specification with the full group of correlates. The results from the first-stage equations are reported as well and suggest three strong identifying instruments for the public works and relief regression - land area, the volatility of the Democratic vote, and church affiliation - and three strong identifying instruments for the AAA - turnout, latitude, and longitude. The first-stage public works and relief regression shows that land area and the volatility of Democratic support contributed to statistically significantly higher New Deal spending, as expected. Increased church membership was associated with lower New Deal spending, suggesting that church activity may have substituted for federal New Deal intervention. The other three identifiers had statistically insignificant effects. In the first-stage AAA regression, the latitude and longitude effects suggest that more western and more northern counties fared better, while counties with higher turnout attracted relatively more AAA funds. The remaining three instruments had statistically insignificant effects. For both first-stage equations, the Hausman test does not reject the hypothesis that the six identifying instruments as a group and the second-stage error term are uncorrelated at the 10 percent confidence level. F-tests reject the hypothesis that the coefficients of the six instruments were simultaneously equal to zero in the two firststage regressions at the 1 percent level. The F-statistic was 3.56 for the public works and relief regression and 14.1 for the AAA. Finally, the Hahn-Hausman test rejected the hypothesis of weak instruments. ${ }^{20}$ 
The results of the second-stage 2SLS equation show that public works and relief grants had a strong positive and statistically significant effect on retail sales growth. An OSD increase in public works and relief grants over the course of the 1930 s led to a 0.97 standard deviation increase in retail sales growth. An additional dollar of per capita New Deal spending during the 1930 s contributed to a 44 cent increase in per capita retail sales in 1939. Considering that 53 percent of income was spent on retail purchases, we can roughly estimate that the additional dollar of New Deal relief would have raised income in 1939 by 85 cents. $^{21}$

Meanwhile, the AAA program that paid farmers to take land out production was associated with lower retail sales growth, although we cannot reject the hypothesis of no effect. An OSD increase in AAA grants was associated with a 0.09 standard deviation reduction in retail sales growth. An additional per capita dollar of AAA spending would have caused 1939 per capita retail sales to be 4 cents less than it otherwise would have been. While the farmers who received payments from the AAA may have benefited from the program, the offsetting reduction in incomes and opportunities for farm laborers, sharecroppers, and tenants seems to have exerted a stronger negative effect on economic activity.

Table 3 also shows the impact of the other correlates on the change in retail sales during the 1930s. Retail sales growth was typically higher in more urban areas and in areas with a higher share of the population aged 30-34. We were surprised to find that areas where there were a higher share of blacks and illiterates did not fare as poorly in terms of retail sales growth as we might have expected.

Geography mattered. The shocks to the economy during the 1930s harmed areas with access to major rivers relatively more, although the downturn was lessened in areas with coastal access to the Gulf of Mexico. Areas with much greater differences in the maximum and minimum elevation fared worse, while areas with higher maximum elevation benefited. The primary influence of climate came through extremes in weather. Areas with more extreme or severe wetness experienced slower retail sales growth, while farm areas that experienced extreme or severe drought fared even worse. Areas with higher per capita retail sales in 1929 experienced slower growth during the 1930s, suggesting some degree of 
convergence. Finally, the trends of the 1920 s seem to have carried over to the 1930 s. Counties with more rapid population growth in the 1920s experienced higher retail sales growth in the 1930s.

\section{VI.1 Alternative Estimates of the Impact of the New Deal, 1929-1935 and 1933-1939}

Our estimates of the 1929-1939 growth in retail sales focuses on the economy's recovery to preDepression levels of economic activity over the entire course of the 1930s, but it is possible that the impact of the New Deal might have been different if we focus on different time periods. We perform robustness checks on our 1929-1939 findings by looking at the growth in retail sales from 1929 through 1935 and from 1933 to 1939 . Analysis of these sub-periods has to be considered substantially more speculative than the 1929-1939 comparisons because dividing the aggregate New Deal information into sub-periods required certain assumptions, particularly for the public works spending. These assumptions are discussed in Appendix 1. Especially for the 1929-1935 estimation, we might have exacerbated the endogeneity problem if we have not fully separated pre-1935 from post-1935 public works spending. In other words, if our parsing methods have not fully eliminated post-1935 variation in public works spending, then retail sales growth through 1935 may be correlated with our estimated measure of relief and public works spending during the First New Deal.

Panel B in Table 4 indicates that the results from the 1929-1935 sub-period follow the same general patterns found in the 1929-1939 analysis. As before, the OLS results show very small effects of public works and relief grants and a negative and statistically insignificant effect of the AAA. In performing the 2SLS analysis, the instrument set differs somewhat from the 1929-1939 analysis. When we used the full set of instruments from the 1929-1939 estimation in the 1929-1935 analysis, the Hausman test rejected the hypothesis that the instruments were uncorrelated with the second-stage error. Upon closer examination we found that the source of the correlation was the exclusion of latitude from the second-stage, therefore we added latitude and longitude to the list of correlates in the retail sales growth equation. Similar to the 1929-1939 analysis, the volatility of Democratic support, church membership, and land area had the expected statistically significant effects in the first stage, while voter turnout had the expected effect in the AAA equation. The Hausman test suggests no correlation of these 
instruments with the second-stage error term and the Hahn-Hausman test does not indicate a weak instruments problem.

The 2SLS coefficients again suggest that public works and relief promoted retail sales growth from 1929 to 1935. An OSD increase in per capita public works and relief led to a 0.56 standard deviation rise in retail sales growth. Meanwhile, AAA grants retarded growth, although we cannot reject the hypothesis of no statistical effect. It is not surprising that early New Deal spending on relief and public works had smaller effects in the short-run because the primary stimulus in the first two years was likely the hiring of the unemployed under the work relief programs and the direct transfer of relief benefits to unemployables. The more general productivity benefits from roads and other infrastructure projects would not have been realized until the projects were completed, which in many cases would have come toward the end of the period

Between 1929 and 1933 the economy experienced a stunning downturn which varied across counties. To measure the significance of the New Deal in pulling counties out of the depths of the Depression, we estimate a 1933 to 1939 growth rate equation. Again, the credibility of this exercise depends on our ability to separate New Deal spending in 1933 from 1934 to 1939 . If the distribution of New Deal grant spending in 1933 was the same as in later years, then the difference in New Deal spending between 1933 and 1939 would be some percentage of the average annual level of New Deal spending for the entire period. To the extent that the actual spending in each county during the last 6 months of 1933 did not follow the same geographic pattern as in the later years, we will have measurement error.

Panel C of Table 4 shows that the results for 1933-1939 are similar to the 1929-1939 estimates. Public works and relief stimulated the recovery from the trough of the Depression, while the AAA had no statistical effect. The OSD effect of the public works and relief on retail sales growth is 0.91 standard deviation. The six instruments we used in the 1929-1939 analysis are used in this sub-period, as the statistical criteria we have established for the instruments have been met. Finally, in this 1933-1939 analysis, we control for the starting point by including per capita retail sales in $1933 .^{22}$ 


\section{Conclusion}

Over the past decade, there have been a number of challenges to the view that the New Deal promoted economic recovery. Several economic studies suggest that various New Deal programs slowed the recovery either by adding inflexibility to the economy or by raising the level of political uncertainty. The New Deal programs that most directly affected the lives of unemployed Americans during the Great Depression were the emergency spending and public works programs, such as the FERA, CWA, WPA, and PWA, and the farm programs. The New Deal distributed large sums of money to state and local governments to provide employment and relief and to build a wide array of public works. The New Deal paid farmers to change their production patterns in an attempt to raise commodity prices. Nearly all of these grants represented a substantial and novel change in the federal government's intervention in local economies.

The conventional Keynesian thinking during the New Deal was that federal spending to employ millions of workers and to purchase materiel for public works would lead to economic growth. Of course, the federal projects might have simply crowded-out private spending or in the case of the AAA there were explicit provisions that required farmers to reduce their production. What complicates the analysis is that New Deal spending might have stimulated economic growth, but it was slower economic growth that might have encouraged policy makers to spend more. In fact, the simple OLS regression of retail sales growth on the two categories of grants suggests that the variation in New Deal spending across the country explains very little of the difference in retail sales growth. To the extent that New Deal administrators chose to allocate more to areas with slower growth, the OLS coefficients will be biased downward because of this endogeneity.

When we control for the endogeneity using 2SLS, the results suggest that New Deal public works and relief grants indeed stimulated local economies. If a county had public works and relief spending that was one standard deviation greater than the mean, its retail sales growth would have been about one 
standard deviation greater than the sample mean. Our estimates suggest that an added dollar of public works and relief spending during the 1930s was associated with a 44 cent increase in per capita retail sales in 1939. This result might suggest that an added per capita dollar of relief spending raised income by roughly 83 cents.

In contrast, the AAA program, which became the basis for our modern farm programs, had little or no positive effect on retail sales and, perhaps, incomes. In fact, the AAA might have had a substantial negative effect. Historical analyses of the AAA suggest that non-landowners at the lower end of the agricultural income distribution suffered declines in income as a result of the AAA. Our results are consistent with this view, as they suggest that the decline in retail sales from lowering the incomes of farm laborers outweighed the rise in retail sales of the farm owners who received most of the payments. The structure of the AAA altered landowners' incentives in such a way that income was redistributed from laborers at the lower end of the skill distribution to landowners. The redistribution of income that the AAA initiated may have retarded the recovery of the local retail sector. 


\section{Appendix 1}

\section{Data Appendix}

Retail sales information from 1933 and 1935 is from U.S. Department of Commerce, Bureau of Foreign and Domestic Commerce, 1936 and 1939. The 1929 and 1939 retail sales information is from Historical, Demographic, Economic, and Social Data: The United States, 1790-1970, ICPSR tape number 0003, as corrected by Michael Haines. The population figures used to create our per capita estimates for 1929, 1933, 1935, and 1939 retail spending were calculated using linear interpolations of the 1930 and 1940 populations. We calculated 1929 population as 1930 minus the average change in population between 1930 and 1940; we did not use trends from 1920 to 1930 due to changes in county boundaries during the 1920s. New Deal spending information is from the Office of Government Reports, 1940. In the case of the AAA farm payments, we had information for 1933 through 1937. Assuming these funds were representative of the whole period's spending, we scaled the four year's of information to six years by multiplying by 1.5. All monetary variables in our analyses were translated into 1967 dollars using the Consumer Price Index (CPI) (Bureau of Census, 1975, series E-135, pp. 211-2). For the New Deal funds, we used the average annual CPI over the period 1933 to $1939(0.412)$ and 1933 to 1935 (0.4). After the substantial deflation from a peak CPI of .513 in 1929 to a trough of .388 in 1933 , the CPI then bounced around between .4 and .43 between 1934 and 1939 (see also Romer, 1999).

The percent black, percent urban, percent of land on farms, percent illiterate, and manufacturing workers in 1929 as a share of the adult population in 1930 are from the 1930 and 1940 files in ICPSR tape 0003, as corrected by Michael Haines. In counties where the number of manufacturing workers was missing, we inserted a zero, so there is some measurement error in that variable. The percentages of the population in each age group are from the Gardner and Cohen ICPSR file (ICPSR 0020). "Dust Bowl” counties were obtained from Hansen and Libecap (forthcoming).

The variables that we use as instruments for New Deal spending include land area, presidential voting variables, the latitude and longitude of the county seats, and church membership as a share of the population in 1926. The land area measure comes from the 1930 Census, ICPSR tape number 0003, as 
corrected by Michael Haines. The presidential voting variables - the standard deviation of the Democratic share of the presidential vote from 1896 to 1928 and the percent of adults voting in 1928 were calculated using information from the ICPSR's United States Historical Election Returns, 1824-1968 (ICPSR tape number 0001). In some cases there were missing values for the percent voting for president, so we used averages from the contiguous counties in their place. Our measure of population from 1920 comes from ICPSR file number 0003, corrected by Michael Haines. There were some county boundary changes between 1920 and 1930; in those cases we estimated the earlier population for the counties based on the growth rates from 1920 to 1930 in the combined counties. From this information we also calculated the population growth rate from 1920 to 1930.

The latitude and longitude from county seats came from ICPSR data set 8159 created by Robert Sechrist. We made several corrections to the original data set: Dutchess, NY latitude 41.45; Greene, PA longitude 80.12; Moultrie, IL latitude 39.35; Fulton, IN latitude 41.07 longitude 86.15; Rock, Nebraska longitude 99.32; Butte, SD latitude 44.38; Campbell, SD latitude 45.44; McCook SD latitude 43.39; Webster, GA latitude 32.04; Greene, NC latitude 35.28, longitude 77.45; Sampson, NC latitude 35.0; Wake, NC latitude 35.45; Rains, TX latitude 32.52; Fulton, KY latitude 36.33; Custer, OK longitude 98.57; Carbon, MT longitude 109.2; Santa Fe, NM latitude 35.4; Mendocino, CA latitude 39.09, longitude 123.12; and Multnomah, OR longitude 122.4.

Church membership data come from the Census of Religious Bodies, 1926, as reported in U.S. Bureau of Census (1980). All of the new counties formed in the 1920s were in place by 1926 . There were some boundary changes for a few counties between 1926 and 1929 that may have caused some measurement error in the population denominator.

The data set consists of 3,060 counties and county/city combinations in the United States. The New Deal program information was reported for some combined counties. For example, the New Deal information was reported for all of New York City. Thus, in New York state, Bronx, King, New York, Queens, and Richmond counties were combined into New York City. Similar situations developed in other states. In Missouri St. Louis City and County were combined. In Virginia we combined the 
following districts that were reported separately in the Census: Albemarle county and Charlottesville city; Allegheny county and Clifton Forge city; Augusta county and Staunton city; Campbell county and Lynchburg city; Dinwiddie county and Petersburg city; Elizabeth City county and Hampton city; Frederick county and Winchester city; Henrico county and Richmond city; Henry county and Martinsville city; James City county and Williamsburg city; Montgomery county and Radford city; Nansemond county and Suffolk city; Norfolk county with Norfolk city, South Norfolk city; and Portsmouth city; Pittsylvania county and Danville city; Prince George county and Hopewell city; Roanoke county and Roanoke city; Rockbridge county and Buena Vista city; Rockingham county and Harrisonburg city; Spotsylvania county and Fredericksburg city; Warwick county and Newport News city; Washington county and Bristol city; Arlington county and Alexandria city. A small number of counties were dropped from the sample due to missing values for the variables above.

In estimating the model for the 1929-1935 difference we divided the information into the First and the Second New Deals. For the annual average New Deal spending up to 1935 we used the following assumptions in splitting the spending into 1935 and earlier and 1936 and later. The OGR reported county data for the AAA spending separately for the rental and benefit payments from 1933 through 1935 and for the conservation payments in 1936 and 1937, so we used only the Rental and Benefit payments for 1933 through 1935. Under relief spending, the Civil Works Administration was in place from November 1933 through March 1934 and thus can be placed in the early period. Similarly, the Federal Emergency Relief Administration ran through June 1935 with a very small amount of spending flowing over into the calendar years 1936 and 1937 as some programs wound down. Because the WPA did not start until July 1935 and less than 6 percent of the employment occurred in 1935 (see U.S. Federal Works Agency, 1940, p. 413), we did not include the WPA spending in the 1935-1929 regressions. All Social Security Administration spending for Aid to the Blind, Old-Age Assistance, and Aid to Dependent Children occurred after January of 1936, so it was not included in the earlier period's regression. For public works expenditures we used information from the OGR's Report number 9 for the states to determine the percentage of spending by the Public Works Administration, Public Roads Administration, and Public 
Buildings Administration that was spent prior to June 30, 1935, for each state and then applied those percentages to the counties in the state.

The climate data are available from the National Climatic Data Center (NCDR). Text files of the data were accessed from ftp://ftp.ncdc.noaa.gov/pub/data/cirs/ (August 2003). The NCDR reports historical monthly data by climate division within each state, so each county's climate information pertains to its respective climate division. In some cases a county was located within two or three divisions. In these cases, the county's climate information was calculated as the average across the climate divisions in which it was located.

Using maps we developed dummy variables for coastal access to the Atlantic coast, the Pacific coast, the Gulf coast, and to the Great Lakes. A county was considered on a coast if it touched the major body of water or was on a bay, sound, or major river that might be considered to have direct access. Thus, the Washington counties on Puget Sound are considered Pacific coastal counties by this definition. Counties on the Chesapeake and Potomac, the southern parts of the Hudson River, and the counties up to Philadelphia are considered Atlantic coast counties.

Roger Paine and Joe Johnson of the U.S. Geological Survey provided a list of all "streams" contained in the USGS's Geographic Names Information System (GNIS), along with a list of counties in which each stream is currently located. This information also can be obtained stream-by-stream through a query at http://geonames.usgs.gov/pls/gnis/web_query.gnis_web_query_form (August 2003). The GNIS database contains over 100,000 stream names because a stream is broadly defined to included creeks and rivers. Each stream is numerically coded, so we performed frequencies to determine the number of counties through which each stream flows. Since our goal is to measure whether a county had access to a river that might have facilitated trade, we developed a series of dummy variables describing whether a county contained a stream that flowed through a specified number of counties. For example, the first dummy variable takes the value 1 if a county contained a stream that ran through more than 50 counties, and 0 otherwise. Only the Mississippi, Missouri, and Ohio Rivers ran through as many as 50 counties, and they are the major rivers in the Eastern and Midwestern United States. A second dummy describes 
access to rivers passing through 21 to 50 counties (includes the Red, Arkansas, Tennessee, Snake, Rio Grande, Canadian, Chattahoochie, Columbia, Brazos, Cumberland, Colorado, White, Cimarron, Des Moines, and James). A third dummy variable measure access to rivers passing through 11 to 20 counties, which includes the next largest 53 rivers. Of the rivers passing through more 10 counties, most are considered navigable by modern Army Corps of Engineers definitions. The rivers not listed as navigable are mostly western rivers and include the Niobrara, Sheyenne, Washita, Catawba, Cheyenne, North Canadian, Canadian, Smoky Hill, Alapaha, Big Sioux, Neches, Pecos, Wisconsin, Yellowstone, Des Moines, Rio Grande, Nueces, Platte, Big Black, Rio Brazos, Cimmarron, Wapsipinicon, and Sabine. Finally, we created a dummy variable reflecting access to a river passing through 5 to 10 counties, which included 384 rivers.

We used a relatively coarse measure of access because the Geological Survey staff warned us that sometimes the same river might have multiple feature numbers. On the other hand, there are also quite a few stream names that appear multiple times but are clearly not connected. We examined the situation for the major rivers and found that this was not a significant problem for them.

We developed a series of variables to describe the elevation range and maximum elevation and information on the number of bays, lakes, beaches, etc., as reported in the USGS's Geographic Names Information System. The information was downloaded in August 2003 from http://geonames.usgs.gov/stategaz/index.html. The data set describes features noted on small-scale topographical maps, including mouths of streams, lakes, valleys, summits, cliffs, bayous, beaches, etc.

There were some county boundary changes between 1940 and 2000. In situations where new counties were carved from older counties, we have merged the new county information back into the older counties for our historical purposes. La Paz County in Arizona was taken from Yuma County and Cibola County in New Mexico was carved from Valencia County. Virginia developed a new set of independent cities and their information was merged back into the county/city combinations that we developed for the New Deal. We did not pay close attention to situations where parts of some counties were annexed to others, but we do not believe this to be a serious problem. We did little with Broomfield 
County, Colorado, an urban county formed from several counties in 2001, because Broomfield had few natural features listed. Since 1940, Washabaugh County, South Dakota was merged into Jackson County and Washington County was merged into Shannon County. To determine the geographic features for Washabaugh County, therefore, we used any features above latitude 43.72694 from Jackson County. This may overstate some features in Washabaugh. Geographic features of Washington County were taken from Shannon County below latitude 43.30139.

Appendix Table 1 reports summary statistics of all variables used in the analysis. 


\section{Appendix 2}

\section{A Model of the Impact of New Deal Spending on Retail Sales}

This appendix provides a framework for understanding how various factors might have influenced the reduced-form effect of New Deal spending on retail sales growth that we estimate. We believe it would be valuable to identify the individual effects on these multiple relationships, but data limitations force us to ask the much simpler question, what was the overall impact of New Deal grant spending on consumption?

Our analysis builds on a model of fiscal federalism suggested by Wallace Oates (1973, 22-29), which is based on a standard regional model in which citizens consume a mixture of goods produced inside and outside their counties and export goods to other counties. Since we are interested in showing the impact of an additional dollar of New Deal grants on the growth rate of retail sales, we develop this discussion in terms of changes in the relevant variables. In the course of the section, we show that changes in all of the variables are influenced to some degree by changes in New Deal grant spending, so the reduced-form impact is obtained through a series of algebraic substitutions. All monetary variables discussed below are assumed to be in per capita terms.

Increases in after-tax income cause increases in the demand for goods (retail sales), which lead to increases in the total revenue of retail sales, assuming an upward sloping or flat supply curve in the retail market. Thus, the relationship between changes in retail sales and changes in after-tax income can be expressed as

$$
\Delta R_{i}=r\left(1-t_{f}\right)\left(\Delta Y_{i}-\Delta T_{i s l}\right)
$$

where $\mathrm{i}$ indexes the county, $\Delta \mathrm{R}_{\mathrm{i}}$ is the change in retail sales, $\mathrm{r}$ is the share of disposable income devoted to retail sales, $\Delta \mathrm{Y}_{\mathrm{i}}$ is the change in income, $\mathrm{t}_{\mathrm{f}}$ is the federal income tax rate, and $\Delta \mathrm{T}_{\mathrm{isl}}$ is the change in lumpsum state and local taxation, which is assumed to be tax deductible for federal tax purposes.

The change in county i's income can be written as the sum of the following changes:

$$
\Delta \mathrm{Y}_{\mathrm{i}}=\Delta \mathrm{PI}_{\mathrm{i}}+\Delta \mathrm{X}_{\mathrm{i}}-\Delta \mathrm{M}_{\mathrm{i}}+\Delta \mathrm{ND}_{\mathrm{i}}+\Delta \mathrm{SL}_{\mathrm{i}}
$$


where $\Delta \mathrm{PI}_{\mathrm{i}}$ is the change in private spending within the county on goods and services produced within the county, $\Delta \mathrm{X}_{\mathrm{i}}$ is the change in private income from production exported outside the county, $\Delta \mathrm{M}_{\mathrm{i}}$ is the change in goods and services imported from outside the county, $\Delta \mathrm{ND}_{\mathrm{i}}$ is the change in federal New Deal grants, and $\Delta \mathrm{SL}_{\mathrm{i}}$ is the change in state and local government spending.

The change in private spending on goods and services produced within county $\mathrm{i}, \Delta \mathrm{PI}_{\mathrm{i}}$, is influenced by changes in after-tax disposable income and in New Deal spending,

$$
\Delta P I_{i}=y\left(1-t_{f}\right)\left(\Delta Y_{i}-\Delta T_{i s l}\right)
$$

where y reflects the share of after-tax income allocated to employing unemployed resources and purchasing local goods in county $i$. The change in goods imported from outside the county, $\Delta \mathrm{M}_{\mathrm{i}}$, is influenced by changes in disposable income and in New Deal spending,

$$
\Delta \mathrm{M}_{\mathrm{i}}=\mathrm{m}\left(1-\mathrm{t}_{\mathrm{f}}\right)\left(\Delta \mathrm{Y}_{\mathrm{i}}-\Delta \mathrm{T}_{\mathrm{isl}}\right)+\mathrm{m}_{\mathrm{s}} \Delta \mathrm{SL}_{\mathrm{i}}+\mathrm{m}_{\mathrm{n}} \Delta \mathrm{ND}_{\mathrm{i}}
$$

where $m$ denotes the share of additional after-tax income that county residents used to purchase goods and services outside the county. Similarly, $\mathrm{m}_{\mathrm{s}}$ and $\mathrm{m}_{\mathrm{n}}$ are shares of state/local and New Deal outlays, respectively, that government decision-makers devoted to purchases from outside the county. ${ }^{23}$

Private income from goods sold outside the county, $\Delta \mathrm{X}_{\mathrm{i}}$, might also have been influenced by changes in New Deal outlays, such that

$$
\Delta \mathrm{X}_{\mathrm{i}}=\mathrm{b} \Delta \mathrm{ND}_{\mathrm{i}}
$$

For example, the AAA program required that recipients of AAA grants take land out of production as a condition of the grant. Thus, we should expect that the amount of private income from farm goods sold outside the county would have been reduced, leading to a negative b. Work relief spending might also have had negative effects on private income from production, as Wallis and Benjamin (1981 and 1989) found that an extra work relief job crowded out approximately half a job in the private sector. New Deal spending within county i might also have had positive effects $(b>0)$ on private production for export if it was devoted to building infrastructure that cut transport costs to other areas and thus raised the net price that local sellers received. Cuts in production costs from New Deal infrastructure potentially had either 
positive or negative effects on local incomes based on the extent to which the productivity enhancements substituted for or complemented labor. There also remains the possibility that the improvements in private productivity from the additions to civil infrastructure had no short-term effect on private incomes as it expanded the production-possibilities without stimulating demands for the products.

An influx of federal spending can lead to responses by state and local governments, so we assume the functional relationship

$$
\Delta \mathrm{SL}_{\mathrm{i}}=c \Delta \mathrm{ND}_{\mathrm{i}}
$$

The literature on flypaper effects and matching grants suggests that increases in federal spending like the New Deal can lead to increases in state and local spending, which would imply that c is positive.

Alternatively, the literature on crowding out suggests that increases in federal spending might cause state and local governments to reduce their own spending and taxation. In this case, c would be negative.

An important factor that could have influenced the ultimate impact of New Deal spending or state and local spending during the Depression was the extent to which they were funded by state and local taxation. As a result, we specify

$$
\Delta \mathrm{T}_{\mathrm{isl}}=\mathrm{w} \Delta \mathrm{SL}_{\mathrm{i}}
$$

Substituting equation (2.6) into (2.7) yields

$$
\Delta \mathrm{T}_{\mathrm{isl}}=\mathrm{w} \mathrm{c} \Delta \mathrm{ND}_{\mathrm{i}}
$$

State and local governments faced significant legal restrictions in their ability to run deficits during the 1930s. Even when the governments ran temporary deficits, however, the bulk of the bonds were sold in markets outside the local jurisdiction and thus repayment of the debt at market interest rates was likely to be expected. Thus, a balanced budget $(\mathrm{w}=1)$ assumption, where increases in state and local spending are matched by increases in taxation, is reasonable. To the extent that state and local governments had more leeway to run deficits and obtain subsidized interest rates, w might be assumed less than one. ${ }^{24}$ 
We can obtain a reduced-form equation with the change in retail sales as a function of the change in New Deal grants by substituting from equations $2.3,2.4,2.5,2.6$, and 2.8 into the change in income equation (2.2). Equation 2.2 can then be rewritten as the change in income as a function of the change in New Deal spending and all of the parameters. We then can substitute from the new version of equation 2.2 into the retail sales equation (2.1), which then yields:

$$
\Delta \mathrm{R}_{\mathrm{i}}=\mathrm{r}\left(1-\mathrm{t}_{\mathrm{f}}\right)\left[1 /\left(1-\left(1-\mathrm{t}_{\mathrm{f}}\right)(\mathrm{y}-\mathrm{m})\right)\right] *\left[1-\mathrm{m}_{\mathrm{n}}+b+\left(1-\mathrm{m}_{\mathrm{s}}-\mathrm{w}\right) \mathrm{c}\right] \Delta \mathrm{ND}_{\mathrm{i}}
$$

Define $\Pi$ to be the base multiplier:

$$
\Pi=\left(1-t_{f}\right) /\left[\left(1-\left(1-t_{f}\right)(y-m)\right]\right.
$$

The base multiplier increases in value as the share of extra spending on purchases of unemployed local resources and local goods and services (y) produced inside the county rises and as the share of goods and services imported into the county (m) falls. Higher federal taxes will reduce the size of the multiplier. Everybody in the U.S. faced the same federal tax schedule, and federal tax payments were triggered by increases in income at the higher end of the income distribution. To the extent that increases in income triggered more federal tax payments the multiplier is reduced. The multiplier is not greatly affected by the federal tax rate on income $\left(\mathrm{t}_{\mathrm{f}}\right)$, because less than 7 percent of households paid income taxes and federal taxes accounted for roughly 7 percent of national income at the time. Estimates of base multipliers for employment with more recent county-level data suggest values ranging from 1 to 2.5 (Vias and Mulligan 1997). ${ }^{25}$ There is the potential for higher estimates during the 1930s because the unemployment rates were at record levels.

Let $\beta$ be the reduced-form relationship measuring the impact of an additional dollar of New Deal spending in county $i$ on retail sales. That is,

$$
\beta=\mathrm{r} \Pi\left[1-\mathrm{m}_{\mathrm{n}}+b+\left(1-\mathrm{m}_{\mathrm{s}}-\mathrm{w}\right) \mathrm{c}\right]=\mathrm{r} \mu
$$

The reduced form parameter $\beta$ summarizes the various channels through which New Deal spending influenced retail sales and $\mu$ is the income multiplier after all influences are accounted for. To get a sense of what might be reasonable values to expect for $\beta$ and $\mu$, Appendix Table 6 shows how different values 
of the key parameters would affect the hypothesized impact of New Deal spending on retail sales. Although the reduced-form parameter is composed of several underlying parameters, we can make educated guesses about some of their values, while others have very little impact on the predicted value of $\beta$. The parameters that have the largest impact on $\beta$ are the extent to which added income is spent on local versus non-local goods and services ( $\mathrm{m}$ and $\mathrm{y}$ ) and the response of private production (b) to New Deal grants.

In general, we have a good sense of the following parameter values, none of which is specific to the type of New Deal program. Estimates from national data suggest a ratio of retail sales to personal income of roughly .53. If income elasticity for retail sales was one, we can reasonably assume that the $r$ will remain the same for different income levels. Alternative income elasticities suggest that the range of the ratio for income levels 20 percent above or below or the mean would be within the range of .5 to .6. If we find that an additional dollar of New Deal spending raised retail sales by .53 , it would suggest that income in the county rose by approximately one dollar, i.e. an income multiplier $(\mu)$ of 1 . It is possible that the marginal $\mathrm{r}$ might differ from the average $\mathrm{r}$. As $\mathrm{r}$ increases toward 1 , so that each additional dollar of income goes to retail sales, the income multiplier converges to the retail sales coefficient. As $r$ falls below, the income multiplier from a retail sales coefficient rises. In Appendix Table 6 we assume a slight state and local government deficit, $w=0.9$, and a state and local crowding out effect $(c=-0.1)$. Changes in the state and local government crowding or matching parameter c have little effect on the reduced-form coefficient because state and local governments faced restrictions on deficit spending. If state and local governments had balanced budgets and focused their spending on goods and services produced inside the county, $w=1$ and $\mathrm{m}_{\mathrm{s}}=0$, the estimated coefficient will reflect no flypaper or crowding-out effects. A reasonable assumption can be made that state and local governments focused their spending on local workers and goods and services, such that only 20 percent of state and local government spending went toward the purchase of goods and services from outside the county $\left(\mathrm{m}_{\mathrm{s}}=0.2\right)$. Changes in this assumption also tend to have very small effects on the final reduced-form parameter. 
The income multiplier $(\mu)$ is the product of the base multiplier, which is common to all programs, and summarizes the productivity, crowding out, and other effects that typically were specific to each program. The key parameters that determine the base multiplier for all programs are y and $\mathrm{m}$, which measure the extent to which people used additional income to buy goods and services locally or outside the county. In the top part of the table, we show the impact of an additional dollar of disposable income when we assume a 20/80 split between purchases from outside the county and spending on local nontradeable goods and unemployed resources $(\mathrm{y}=0.80$ and $\mathrm{m}=0.20)$. When combined with a federal tax rate of 7 percent, the base multiplier is roughly 2.1. When the share of income devoted to local spending and unemployed resources falls to 50 percent further down in the table, the base multiplier falls to 0.93 ; when it rises to 90 percent, the base multiplier rise to 3.63 .

Given the potential base multipliers, we can now see how the income multipliers differ for the two major categories of grant programs. We will focus the discussion on the top part of the table where extra income is spent 80 percent locally or on unemployed resources. Consider the impact of the public works and relief grants. In line 1 we show the impact of these grants if they had no crowding out or positive productivity effects $(b=0)$. Roughly 20 percent of public works spending went for materials and we will assume half of those materials were purchased outside the county $\left(\mathrm{m}_{\mathrm{n}}=0.1\right)$. The combination of assumptions would lead to a reduced-form effect in which an added dollar of relief and public works grants raised income by the income multiplier $(\mu)$ of 1.91 . The ultimate reduced form retail sales effect is obtained by multiplying an $\mathrm{r}$ of 0.53 by the income multiplier to obtain a coefficient of 1.01 (see row 1 of Appendix Table 6). If infrastructure spending boosted private sector profitability a great deal, say $b=0.3$ as in line 1a in the table, the retail sales effect rises to 1.35 and the income multiplier rises to 2.55. Had the relief grants and public works spending caused crowding-out of private employment of 50 percent ( $b=-0.5$ in line $1 b$ of the table), similar to what Wallis and Benjamin (1989) found, the income multiplier would fall to 0.97 and the reduced-form retail sales effect would fall to 0.51 . 
The AAA program potentially had much weaker and even negative effects on incomes and retail sales because of the requirement that land be taken out of production. If the AAA payments simply replaced the lost income from land taken out of production $(b=-1)$, the retail sales coefficient would be 0 . However, the additional reductions in the demand for labor and the decline in the economic status of tenants associated with the AAA could have caused $\mathrm{b}$ to be even more negative, say -1.2. As we see in Line 2a of Table 3, this would imply a retail sales coefficient of -0.22 and an income multiplier of -0.42 .

In summary, the experiment posited in the table suggests that it is not unreasonable to expect that public works and relief spending might raise retail sales by roughly a dollar for every dollar spent if the internal/external split in spending is $80 / 20$ and the net effect of crowding out and enhancing productivity was zero, as in line 1 in the table. After dividing this figure by 0.53 , we obtain an income multiplier of 1.91. Adjustments up and down from these figures would give an indication of the extent to which the programs stimulated private productivity or crowded out private production. AAA spending was likely to have at best a small positive effect and potentially negative effects on retail sales and income. 


\section{FOOTNOTES}

${ }^{1}$ See Black (2003), for example, for a favorable recent assessment of Roosevelt's efforts during the Great Depression.

${ }^{2}$ Macroeconomic investigators Brown (1956) and Peppers (1973) dismiss the New Deal as a true example of Keynesian fiscal stimulus on the grounds that the federal government did not run budget deficits of the size that a Keynesian would have deemed necessary to offset the large gap in unemployment. Bernanke and Parkinson (1989) and DeLong and Summers (1988) suggest that much of the recovery in the latter half of the 1930s was the result of the natural tendency of the economy to return to its steady state. Meanwhile, Romer (1992) finds that the recovery after 1933 was primarily the result of monetary expansion.

${ }^{3}$ See Wallis and Benjamin (1981, 1989), Margo (1993), Sundstrom (1995), and Fleck (1999b).

${ }^{4}$ See Wright (1974), Wallis (1987, 1998, 2001), Anderson and Tollison (1991), Couch and Shughart (1998), Fleck (1999a, 1999c, 2001a, 2001b), and Fishback, Kantor, and Wallis (2003). Powell's (2003) recent book paints a negative picture of the effectiveness of the New Deal, while citing many of these studies.

${ }^{5}$ Since our analysis throughout the paper focuses on per capita retail sales, we will henceforth use "retail sales" and "per capita retail sales" interchangeably.

${ }^{6}$ See U.S. Senate 1935, pp. xi-xiv and Williams 1966, p. 212. In its publicity publications, the U.S. Public Works Administration (1939, 20-22) traced the paths of workers' spending to show the impact of the PWA on retail sales and the rest of the economy.

${ }^{7}$ See series T81 deflated by series E135 and series F4 in U.S. Bureau of the Census 1975, pp. 210-11, 224, and 843. See also Romer (1992).

${ }^{8}$ New Deal spending did not encompass all federal spending, so our analysis does not address the impact of all forms of federal expenditures. It should be noted, however, that much of the New Deal represented an entirely new role for the federal government. For example, agricultural spending, relief spending, many forms of lending to state and local governments, and insurance of mortgage loans broke new 
ground for the federal government. In addition, there were major increases in federal spending from the early 1930s on roads, public buildings, public works, and conservation. The New Deal programs caused federal intergovernmental and direct outlays on education to rise from 26 million in 1932 to 235 million in 1934, on highways from 217 million to 599 million, on public welfare and employment security from 2 million to 585 million, on housing and urban renewal from 0 in 1932 to 3 million in 1934 to 71 in 1936. Spending on the primary tasks of the federal government prior to the 1930s generally did not display the same marked jumps. See Wallis 1985 and U.S. Bureau of Census 1975, pp. 1124-26.

${ }^{9}$ Much of the debate over the determinants of the state-level distribution of New Deal spending relied on information from the Office of Government Reports. Recently, scholars have expanded the debate to use the county-level information. See Fishback, Kantor, and Wallis (2003) for a table that summarizes the various studies of the distribution of federal New Deal expenditures. Couch, Atkinson, and Wells (1999) and Couch and Williams (1998) have used county-level data from Alabama to examine the distribution of New Deal agricultural and total funds. Using another data source, Fleck (1994, 1999b, 2001a) has used county-level data to examine the distribution of relief and its impact on unemployment.

${ }^{10}$ The Office of Government Reports also provided information on $\$ 10.4$ billion in repayable loans under a variety of programs as well as data on the Federal Housing Administration's insurance of \$2.7 billion in mortgage loans. We do not focus attention on these programs for several reasons. First, the nature of the loans and insurance were substantially different from the nonrepayable grants and it is hard to determine the true dollar size of the benefits that the counties received. A substantial portion of the loans were repaid within a relatively short period of time and the grant feature of the loans would have come in the form of favorable interest rates and repayment terms. The OGR did not provide information on these features, so we have no direct means of estimating the true size of the federal subsidy. Under the FHA program, mortgage lenders approached the FHA for insurance once they had decided to write a mortgage contract that would have satisfied FHA criteria. The federal government's outlays for this program were very small relative to the value of the loans because the FHA was careful in choosing the loans to insure 
and, consequently, paid out less than 1 percent of loan value in insurance claims. Second, in the analysis we seek to reduce problems of endogeneity by using instrumental variables. We face difficulties in finding enough effective instruments that will allow us to simultaneously identify more than two or three New Deal variables in a system of equations. In our attempts to use our group of instruments to simultaneously identify equations where the FHA and loans are included along with the grants as endogenous variables, the 2SLS results contain no statistically significant effects for any variables, which is a sign that the instruments are too weak to identify the system. Third, by omitting the loans and FHA insurance we reduce measurement error at the risk of increasing omitted variables bias in our estimates of the impact of New Deal grants. We do not believe that the bias will be large from omitting the loans and FHA insured loans because these variables are largely orthogonal to the grants variables. We do not anticipate much bias for the public works and relief grants coefficient because the correlations with loans and FHA insured loans are 0.044 and 0.051 , respectively. The AAA grant spending is largely uncorrelated with nonfarm loans and FHA insured loans at -.07 and -.14, respectively. However, the AAA grant spending may be picking up some of the impact of farm loans, because the correlation is high at .75. Fishback, Kantor, and Wallis 2003 find that the determinants of the geographic distribution of farm loans and AAA grants were similar.

${ }^{11}$ We summarize these effects here and provide a more formal description of the various interactions in Appendix 2. The framework we develop in the appendix is based on Oates's (1973) model of fiscal federalism.

12 There also remains the possibility that the improvements in private productivity from the additions to civil infrastructure had no short-term effect on private incomes as it expanded production-possibilities without stimulating demands for the products. Recent empirical work investigating the impact of civil infrastructure on economic growth gives mixed support to the hypothesis that more infrastructure spending leads to substantial increases in economic growth. See Aschauer 1989; Costa, Ellson, and 
Martin 1987; Duffy-Deno and Eberts 1991; Hulten and Schwab 1991; Garcia-Mila and McGuire 1992; Munnell 1992; Gramlich 1994; Fernald 1999; and Pereira and Flores de Frutos 1999.

${ }^{13}$ See Gramlich 1977, Hines and Thaler 1995, and Bailey and Connolly 1998 for discussions of ways in which different types of grants influence total state and local spending. The WPA and FERA contained matching provisions in their original legislation. The FERA matching provisions were largely ignored after November 1933. The actual share of the WPA and FERA projects financed by the state and local governments varied dramatically from project to project in ways that suggest no consistent matching formula. For information on the WPA's matching provisions, see Howard $(1943,147)$ and for the FERA see Williams (1966, 217).

${ }^{14}$ This is an estimate at the mean of retail sales. The same ratio would hold at all levels of retail sales if the elasticity of personal income with respect to retail sales is 1 . To get a sense of the income elasticity, we estimated it for 1929 using a cross-section of state aggregates for per capita personal incomes and retail sales. The elasticity was 0.76 . Using an income elasticity of 0.76 , the ratio of retail sales to personal income would range up to .57 when per capita retail sales are $\$ 100$ above the mean to .50 when per capita retail sales are $\$ 100$ below the mean.

${ }^{15}$ We considered developing a panel data set using the splits in New Deal spending from 1933 to 1935 and 1935 to 1939 . However, the splits are in part determined by assumptions about how to divide public works spending between the two periods and we worried that the variation between 1933 and 1935 and 1935 and 1939 would have been too dependent on our assumptions about the temporal distribution of spending.

${ }^{16}$ See Barro and Sala-i-Martin (2004, 511-66) for a comprehensive overview of the empirical analysis of cross-section growth rates.

${ }^{17}$ The estimated effects of the New Deal are largely unaffected when the prior level of retail sales or the growth in population in the 1920 s is excluded. The same is true when we exclude the geography and climate correlates. We did not include population growth from 1929 to 1939 in the retail sales growth 
equation to avoid adding another endogenous variable to the system. In another study, Fishback, Kantor and Horrace (2001) have examined the influence of New Deal spending on net migration during the 1930s. Thus, part of the impact of the New Deal on retail sales that we measure might have occurred through its impact on migration.

${ }^{18}$ See Ziliak (1996) on the role of private organizations as a substitute for government relief.

${ }^{19}$ We have also explored the use of several other potential instruments that are discussed in the literature. Wallis $(1998,2001 \mathrm{a})$ argues that New Deal administrators recognized that they had to spend at least a minimum amount in every political jurisdiction. When this factor is taken into account when converting New Deal spending to per capita terms, the inverse of the population becomes an important factor in the analysis; we explored this variable using the inverse of population in 1920. The Roosevelt administration might also have had an incentive to reward those voters who had provided long-term support to the Democratic party to ensure future loyalty. Anderson and Tollison (1991), Fleck (1999b, 2001a), and Fishback, Kantor, and Wallis (2003) have found measures of loyalty to be positively related to New Deal spending. There have been a variety of loyalty measures used in the literature, including Wright's (1974) political productivity index which included the mean level of Democratic voting as a component. To examine the impact of loyalty, we use the mean percentage voting for the Democratic presidential candidate from 1896 to 1928 . Following Fleck (1999b), we have also explored using a prediction of the 1932 share voting Democrat from a regression us of 1932 votes on prior votes for 1896 to 1928 and state dummies. This predicted vote turns out to be very highly correlated with the mean Democratic loyalty from 1896 to 1928 . As we experimented with these additional variables, we found that they generally add little to the explanatory power of the first-stage regressions, the coefficients and t-tests for the New Deal variables in the second-stage are unchanged, and the Hausman tests for correlation between the group of instruments and the second-stage error does not reject the hypothesis of no correlation.

${ }^{20}$ We have performed extensive sensitivity testing of the instruments, see Appendix Table 3 . No single instrument is driving the results. When we remove any one of the six instruments, it does not affect the 
coefficients and standard errors of the remaining instruments in the first-stage. Moreover, the results of the second-stage are generally the same as before. However, the combined strength of the instruments in the first-stage is reduced. In the extreme, when we remove the statistically significant identifying instruments for the public works and relief (church membership, Democratic volatility, and land area), the impact of public works and relief becomes statistically insignificant because we have a weak instruments problem. If we remove all of the statistically significant identifying instruments for the AAA (latitude, longitude, and voter turnout), the basic results for the public works and relief equations are unaffected, but we encounter a weak instruments problem in trying to estimate the effect for the AAA.

Fleck (1999b) suggested an additional test of whether the identifying instruments might still be affecting New Deal spending through their impact on the dependent variable in the second-stage equation. He compared the coefficients of the instruments in the first-stage regression to coefficients from a regression that added the second-stage dependent variable - in our case the growth rate in retail sales - as a variable in the first-stage equation. If the coefficients change substantially this might be a sign that the identifying instruments are influencing the New Deal variables through the change in retail sales. The addition of the retail sales variable to the first-stage equation has very little effect on the coefficients and t-statistics of the identifying instruments in our analyses. Therefore, we do not believe that the instruments are influencing New Deal spending through the dependent variable that we are trying to explain.

${ }^{21}$ We have also estimated the model as the change in the levels of per capita retail sales between 1929 and 1939 as a function of the levels of the right-hand side variables. As shown in Appendix Table 4, the results are essentially the same as those reported for the growth rate specification. Some growth models also use logged values of the right-hand-side variables, so we have estimated the model using logged values of the New Deal variables. Using the logged values leads to results that are generally similar to what we find under the OLS or 2SLS specifications. As shown in Appendix Table 5, in the OLS versions the two programs have small effects. In the 2 SLS versions, public works and relief have larger positive 
effects than the AAA. The AAA effect is negative in two of the three time periods. However, it is not clear how much we can trust these results because we appear to have a weak instrument problem. In particular, the instrument set does a poor job of explaining the logged values of the New Deal public works and relief variable. The entire literature on the distribution of New Deal funds has focused on explaining the levels of New Deal spending per capita, so we were surprised by this change when the New Deal grants are logged. We searched for additional instruments for the logged values and to date have had no success. We are leery of using a specification with logged right-hand-side variables for two other reasons. We end up with an unusual mixture of logged and unlogged values on the right-hand-side because the majority of our control variables are percentages, several of which have large numbers of zero values, and dummy variables that typically are not logged. There are a number of zero values for the AAA, so that we have to resort to using the log of a constant plus the AAA. The results are slightly sensitive to the chose of the constant.

${ }^{22}$ We have also estimated the model by controlling for prior trends by replacing the 1920s population growth with the retail sales growth during the 1929-1933 downturn. The results for the New Deal variables tell the same story, although the OSD effects of public works and relief are larger at 1.41 standard deviations. The coefficient on the downturn variable is negative, consistent with the suggestions by Bernanke and Parkinson (1989) and DeLong and Summers (1988) that mean reversion was a feature of the 1930 s recovery.

${ }^{23}$ Note that after substituting equation 2.4 into equation 2.2, the impact of an added dollar of New Deal spending on local income is $\left(1-m_{n}\right)$ and that of another dollar of state and local spending is $\left(1-m_{s}\right)$. We do not include government spending in the private consumption of internal county production because it would lead to double counting. The sum $m+y$ would equal one if there were no saving.

${ }^{24}$ See Oates 1973 . As of 1932, all of the states ran very large surpluses if capital outlays are excluded from their budgets. The inclusion of capital outlays led to deficits in two-thirds of the states. The states appear to have taken repayment of their debts seriously because by 1937 all but four states ran surpluses 
(including capital outlays as spending), some of which were very large, and three of the remaining four were very close to a balanced budget (U.S. Bureau of the Census 1935, 8-17, 28-39; 1940, 7-16).

${ }^{25}$ For discussions of the theoretical bases for these multipliers, see McGregor, et. al. (2000), Merrifield (1987), and the sources cited therein. The multipliers based on neoclassical principles have assumed that labor markets clear at the prevailing wage. We chose a quasi-Keynesian approach in part for simplicity and in part because throughout the 1930s unemployment rates ranged from 10 to 25 percent. 


\section{REFERENCES}

Acemoglu, Daron, Simon Johnson, and James Robinson, "Reversal of Fortune: Geography and Institutions in the Making of the Modern World Income Distribution," Quarterly Journal of Economics 117 (November 2002), 1231-94.

, "Disease and Development in Historical Perspective," Journal of the European Economic Association 1 (April-May 2003), 397-405

Alston, Lee J., "Tenure Choice in Southern Agriculture, 1930-1960,” Explorations in Economic History, 18 (July 1981), 211-32.

Anderson, Gary M., and Robert D. Tollison, "Congressional Influence and Patterns of New Deal Spending, 1933-1939," Journal of Law and Economics, 34 (April 1991), 161-75.

Aschauer, David Alan, "Is Public Expenditure Productive?" Journal of Monetary Economics 23 (March 1989), 177-200.

Bailey, Stephen J., and Stephen Connolly, "The Flypaper Effect: Identifying Areas for Further Research," Public Choice 95 (June 1998), 335-61.

Barro, Robert J., and Xavier Sala-i-Martin, Economic Growth, second edition (Cambridge, MA: MIT Press, 2004).

Bernanke, Ben, and Martin Parkinson, "Unemployment, Inflation, and Wages in the American Depression: Are There Lessons for Europe?" American Economic Review Papers and Proceedings 79 (May 1989), 210-14.

Biles, Roger, The South and the New Deal (Lexington, KY: University of Kentucky Press, 1994).

Black, Conrad, Franklin Delano Roosevelt: Champion of Freedom (New York: PublicAffairs, 2003).

Brown, E. Cary, "Fiscal Policy in the 'Thirties: A Reappraisal," American Economic Review 46 (Dec. 1956), 857-79.

Clarke, Jeanne Nienaber, Roosevelt's Warrior: Harold L. Ickes and the New Deal (Baltimore: Johns Hopkins University Press, 1996).

Cole, Harold, and Lee Ohanian, "New Deal Policies and the Persistence of the Great Depression: A General Equilibrium Analysis," Journal of Political Economy (forthcoming).

Costa, Jose da Silva, Richard W. Ellson, and Randolph C. Martin, "Public Capital, Regional Output, and Development: Some Empirical Evidence," Journal of Regional Science 27 (Aug. 1987), 419-37.

Couch, Jim, Atkinson, Keith E.; Wells, William H., "New Deal Agricultural Appropriations: A Political Influence. Eastern Economic Journal 24 (Spring 1998), 137-48.

Couch, Jim, and William Shughart II, The Political Economy of the New Deal (New York: Edward Elgar, 1998).

Couch, Jim, and Peter M. Williams. "New Deal or Same Old Shuffle? The Distribution of New Deal Dollars Across Alabama," Economics and Politics 11 (July 1999), 213-23.

Delong, J. Bradford, and Lawrence H. Summers, "How Does Macroeconomic Policy Affect Output?" Brookings Papers on Economic Activity (1988), 433-80.

Diamond, Jared, Guns, Germs, and Steel: The Fates of Human Societies (New York: W. W. Norton, 1997).

Duffy-Deno, Kevin T., and Randall W. Eberts, "Public Infrastructure and Regional Economic Development: A Simultaneous Equations Approach,” Journal of Urban Economics 30 (Nov. 1991), 329-43.

Engerman, Stanley L., and Kenneth L. Sokoloff, "Factor Endowments, Inequality, and Paths of Development among New World Economies," Economia 3 (Fall 2002), 41-88.

Fernald, John G., "Roads to Prosperity? Assessing the Link between Public Capital and Productivity," American Economic Review 89 (June 1999), 619-38.

Fishback, Price V., William C. Horrace, and Shawn Kantor, "Do Federal Programs Affect Internal Migration? The Impact of New Deal Expenditures on Mobility During the Great Depression," National Bureau of Economic Research Working Paper 8283 (May 2001). 
Fishback, Price V., Shawn Kantor, and John Joseph Wallis, "Can the Three R's be Rehabilitated? A Comprehensive Analysis, Program by Program, County by County," Explorations in Economic History 40 (July 2003), 278-307.

Fleck, Robert Kenneth, "Essays on the Political Economy of the New Deal," unpublished Ph.D. dissertation, Stanford University, 1994.

, "Electoral Incentives, Public Policy, and the New Deal Realignment," Southern Economic Journal 63 (Jan. 1999a), 377-404.

, "Inter-party competition, intra-party competition, and distributive Policy: A Model and Test using New Deal Data," Public Choice 108 (July 2001a), 77-100.

"The Marginal Effect of New Deal Relief Work on County-Level Unemployment Statistics." Journal of Economic History 59 (September 1999b): 659-687.

"Population, Land, Economic Conditions, and the Allocation of New Deal Spending." Explorations in Economic History 38 (April 2001b), 296-304.

"The Value of the Vote: A Model and Test of the Effects of Turnout on Distributive Policy," Economic Inquiry 37 (October 1999c), 609-23.

Gallop, John Luke, Jeffrey D. Sachs, and Andrew D. Mellinger, "Geography and Economic Development," in Boris Pleskovic and Joseph E. Stiglitz, eds., Annual World Bank Conference on Development Economics, 1998 (Washington, DC: World Bank, 1999), 127-78.

Garcia-Mila, Theresa, and Therese J. McGuire, "The Contribution of Publicly Provided Inputs to States' Economies," Regional Science and Urban Economics, 22 (June 1992), 229-41.

Gardner, John, and William Cohen, "Demographic Characteristics of the Population of the United States, 1930-1950: County-Level," ICPSR file 0020, 1992.

Gramlich, Edward M., "Infrastructure Investment: A Review Essay,” Journal of Economic Literature, 32 (Sept. 1994), 1176-96.

, "Intergovernmental Grants: A Review of the Empirical Literature." In The Political Economy of Fiscal Federalism. Edited by Wallace E. Oates. Lexington, Massachusetts: Lexington Books, 1977.

Greene, William H., Econometric Analysis, Fifth Edition (New York: Prentice Hall, 2003).

Hahn, Jinyong, and Jerry Hausman, "A new specification test for the validity of instrumental variables," Econometrica 70 (Jan. 2002), 163-89.

Hansen, Zeynep K., and Gary D. Libecap, "Small Farms, Externalities, and the Dust Bowl of the 1930s," Journal of Political Economy (forthcoming).

Hausman, Jerry, "Specification and Estimation of Simultaneous Equations Models," In Zvi Griliches and Michael Intrilligator, eds, Handbook of Econometrics (Amsterdam: North-Holland, 1983).

Higgs, Robert, "Regime Uncertainty: Why the Great Depression Lasted So Long and Why Prosperity Resumed after the War," Independent Review 1 (Spring 1997), 561-90.

Hines, James R. Jr., and Richard H. Thaler, "The Flypaper Effect," Journal of Economic Perspectives 9 (Fall 1995), 217-26.

Howard, Donald S. The WPA and Federal Relief Policy (New York: Russell Sage Foundation, 1943).

Hulten, Charles R., and Robert M. Schwab, "Public Capital Formation and the Growth of Regional Manufacturing Industries," National Tax Journal 44 (Dec. 1991), 121-34.

Inter-University Consortium for Political and Social Research, Historical, Demographic, Economic, and Social Data: The United States, 1790-1970, ICPSR Number 0003. The version has corrections by Michael Haines, Department of Economics, Colgate University, Hamilton, NY.

Inter-University Consortium for Political and Social Research, United States Historical Election Returns, 1824-1968, ICPSR Number 0001.

McGregor, Peter, Eric McVittie, J. Kim Swales, and Ya Ping Yin, "The Neoclassical Economic Base Multiplier," Journal of Regional Science 40 (Feb. 2000), 1-31.

Margo, Robert, "Employment and Unemployment in the 1930s." Journal of Economic Perspectives 7 (Spring 1993), 41-59. 
Merrifield, John, “A Neoclassical Anatomy of the Economic Base Multiplier,” Journal of Regional Science 27 (May 1987), 283-94.

Munnell, Alicia, "Infrastructure Investment and Economic Growth," Journal of Economic Perspectives 6 (Fall 1992), 189-98.

Oates, Wallace, Fiscal Federalism (New York: Harcourt Brace Jovanovich, 1973).

Peppers, Larry, "Full Employment Surplus Analysis and Structural Change: The 1930s," Explorations in Economic History 10 (Winter 1973), 197-210.

Pereira, Alfredo M., and Rafael Flores de Frutos, "Public Capital Accumulation and Private Sector Performance," Journal of Urban Economics 46 (September 1999), 300-22.

Powell, Jim, FDR's Folly: How Roosevelt and His New Deal Prolonged the Great Depression (New York: Crown Forum, 2003).

Rappaport, Jordan, and Jeffrey D. Sachs, "The United States as a Coastal Nation,” Journal of Economic Growth 8 (March 2003), 5-46.

Romer, Christina D., "The Great Crash and the Onset of the Great Depression" Quarterly Journal of Economics 105 (Aug. 1990), 597-624.

"What Ended the Great Depression?" Journal of Economic History 52 (Dec. 1992), 757-84. ,"Why Did Prices Rise in the 1930s?" Journal of Economic History 59 (March 1999), 167-99.

Saloutos, Theodore, "New Deal Agricultural Policy: An Evaluation," Journal of American History 61 (Sept. 1974), 394-416.

Schlesinger, Arthur, The Age of Roosevelt: The Coming of the New Deal (Boston: Houghton-Mifflin, 1958).

Sundstrom, William, "Did the WPA Displace Private Employment? Evidence from the 1940 Census Microsample." Manuscript. Santa Clara University, July 1995.

Temin, Peter, Did Monetary Forces Cause the Great Depression? (New York: W.W. Norton, 1976).

U.S. Bureau of the Census, Censuses Of Religious Bodies, 1906-1936 [Computer file]. ICPSR ed. Ann Arbor, MI: Inter-university Consortium for Political and Social Research [producer and distributor], 1980.

U.S. Bureau of the Census, Financial Statistics of State and Local Governments: 1932 (Washington, DC: GPO, 1935).

U.S. Bureau of the Census, Historical Statistics of the United States: Colonial Times to 1970 (Washington, DC: GPO, 1975).

U.S. Bureau of the Census, "Illiteracy in the United States, October 1947," Current Population Reports: Population Characteristics, Series P-20 no. 20, September 22, 1948.

U.S. Bureau of Economic Analysis, GNP: An Overview of Source Data and Estimating Methods: Methodology Papers: U.S. National Income and Product Accounts (Washington, DC: GPO, 1987).

U.S. Congress, Official Congressional Directory, for the $73^{\text {rd }}$ Congress $1^{\text {st }}$ session through $76^{\text {th }}$ Congress (Washington, D.C.: GPO, various years).

U.S. Department of Commerce, Bureau of Foreign and Domestic Commerce, Consumer Market Data Handbook. (Washington, D.C.: GPO, 1936).

U.S. Department of Commerce, Bureau of Foreign and Domestic Commerce, Consumer Market Data Handbook. (Washington, D.C.: GPO, 1939).

U.S. Department of Commerce, Bureau of Foreign and Domestic Commerce, General Consumer Market Statistics, Supplement 1 to the Market Data Handbook of the United States. (Washington, D.C.: GPO, 1932).

U.S. Farm Credit Administration, Financing Agriculture in 1934 (Washington, D.C: GPO, 1935). , Farm Credit Quarterly, June 1936 (Washington, D.C.: GPO, 1936).

U.S. Federal Housing Administration, Annual Report (Washington, DC: GPO, various years).

U.S. Federal Works Agency, First Annual Report of the Federal Works Agency, 1940 (Washington, DC: Government Printing Office, 1940).

U.S. Office of Government Reports, Statistical Section, Report No. 9, Volume 1, "Direct and Cooperative 
Loans and Expenditures of the Federal Government for Fiscal Years 1933 through 1939.” Mimeo, 1940.

U.S. Office of Government Reports, Statistical Section, Report No. 10, Volume 1, "County Reports of Estimated Federal Expenditures March 4 1933-June 30, 1939,” Mimeo, 1940.

U.S. Public Works Administration. America Builds: The Record of the PWA. Washington, D.C.: Government Printing Office, 1939.

U.S. Senate, "Expenditure of Funds: Federal Emergency Relief Administration. Senate Document No. 56. $74^{\text {th }}$ Congress $1^{\text {st }}$ session. U.S. Govt. Printing Office, 1935.

Wallis, John Joseph, "The Birth of the Old Federalism: Financing the New Deal, 1932-1940," Journal of Economic History 44 (Mar. 1984), 139-59.

,"Why 1933? The Origins and Timing of National Government Growth, 1933-1940," Research in Economic History 4 (1985), 1-51.

"Employment, Politics, and Economic Recovery During the Great Depression," Review of Economics and Statistics 69 (Aug. 1987), 516-20.

, "The Political Economy of New Deal Spending Revisited, Again: With and Without Nevada," Explorations in Economic History 35 (April 1998), 140-70.

"The Political Economy of New Deal Spending, Yet Again: A Reply to Fleck." Explorations in Economic History 38 (April 2001), 305-14.

Wallis, John Joseph, and Daniel K. Benjamin, "Public Relief and Private Employment in the Great Depression," Journal of Economic History 41 (Mar. 1981), 97-102.

"Private Employment and Public Relief During the Great Depression," Department of Economics, University of Maryland working paper, 1989.

Whatley, Warren C., "Labor for the Picking: The New Deal in the South," Journal of Economic History 43 (Dec. 1983), 905-29.

Williams, Edward Ainsworth. Federal Aid for Relief. Reprint of 1939 edition of Columbia University Studies in the Social Sciences (New York: AMS, 1966).

Wright, Gavin, "The Political Economy of New Deal Spending: An Econometric Analysis," Review of Economics and Statistics 56 (Feb. 1974), 30-38.

Ziliak, Stephen T., "The End of Welfare and the Contradiction of Compassion," Independent Review 1 (Spring 1996), 55-74. 
Table 1

Ratios of Per Capita Retail Sales in 1933 and 1939 to 1929 and Distributional Information for Counties Within Each State

\begin{tabular}{|c|c|c|c|c|c|c|c|}
\hline \multirow[b]{2}{*}{ STATE } & \multicolumn{2}{|c|}{$\begin{array}{l}\text { Aggregate State Ratios } \\
\text { to } 1929 \text { Value }\end{array}$} & \multicolumn{5}{|c|}{$\begin{array}{c}\text { Ratio } 1939 \text { to } 1929 \\
\text { Distributional Information for Counties within } \\
\text { State }\end{array}$} \\
\hline & 1933 & 1939 & Mean & $\begin{array}{l}\text { Std. } \\
\text { Dev. }\end{array}$ & Min & Max. & $\begin{array}{l}\# \text { of } \\
\text { Counties }\end{array}$ \\
\hline \multicolumn{8}{|l|}{ NEW ENGLAND } \\
\hline Connecticut & 0.722 & 1.082 & 1.091 & 0.061 & 1.017 & 1.197 & 8 \\
\hline Maine & 0.773 & 1.061 & 1.081 & 0.124 & 0.883 & 1.314 & 16 \\
\hline Massachusetts & 0.764 & 1.027 & 1.064 & 0.087 & 0.924 & 1.268 & 14 \\
\hline New Hampshire & 0.784 & 1.160 & 1.180 & 0.075 & 1.093 & 1.277 & 10 \\
\hline Rhode Island & 0.685 & 1.028 & 1.120 & 0.157 & 0.909 & 1.300 & 5 \\
\hline Vermont & 0.683 & 1.001 & 1.008 & 0.085 & 0.892 & 1.149 & 14 \\
\hline \multicolumn{8}{|l|}{ MID-ATLANTIC } \\
\hline Delaware & 0.706 & 1.171 & 1.284 & 0.169 & 1.102 & 1.435 & 3 \\
\hline New Jersey & 0.721 & 1.027 & 1.043 & 0.108 & 0.831 & 1.227 & 21 \\
\hline New York & 0.680 & 0.908 & 0.985 & 0.099 & 0.795 & 1.291 & 58 \\
\hline Pennsylvania & 0.644 & 0.988 & 1.054 & 0.119 & 0.834 & 1.384 & 67 \\
\hline \multicolumn{8}{|c|}{ EAST NORTH CENTRAL } \\
\hline Illinois & 0.607 & 0.917 & 0.981 & 0.133 & 0.624 & 1.398 & 102 \\
\hline Indiana & 0.602 & 1.016 & 1.042 & 0.146 & 0.755 & 1.592 & 92 \\
\hline Michigan & 0.545 & 0.928 & 1.019 & 0.135 & 0.676 & 1.513 & 83 \\
\hline Ohio & 0.655 & 1.011 & 1.043 & 0.108 & 0.743 & 1.386 & 88 \\
\hline Wisconsin & 0.649 & 0.994 & 1.024 & 0.094 & 0.842 & 1.277 & 71 \\
\hline \multicolumn{8}{|c|}{ WEST NORTH CENTRAL } \\
\hline Iowa & 0.645 & 1.016 & 1.021 & 0.130 & 0.663 & 1.374 & 99 \\
\hline Kansas & 0.595 & 0.819 & 0.747 & 0.150 & 0.373 & 1.118 & 105 \\
\hline Minnesota & 0.710 & 1.094 & 1.132 & 0.159 & 0.899 & 1.911 & 87 \\
\hline Missouri & 0.681 & 0.900 & 0.909 & 0.178 & 0.565 & 1.426 & 114 \\
\hline Nebraska & 0.657 & 0.911 & 0.928 & 0.731 & 0.501 & 7.636 & 93 \\
\hline North Dakota & 0.623 & 0.870 & 0.805 & 0.144 & 0.543 & 1.151 & 53 \\
\hline South Dakota & 0.566 & 0.882 & 0.828 & 0.185 & 0.476 & 1.431 & 68 \\
\hline \multicolumn{8}{|l|}{ SOUTH } \\
\hline Virginia & 0.756 & 1.165 & 1.213 & 0.285 & 0.649 & 2.610 & 100 \\
\hline Alabama & 0.611 & 0.952 & 0.953 & 0.214 & 0.529 & 1.669 & 67 \\
\hline Arkansas & 0.565 & 0.848 & 0.773 & 0.156 & 0.459 & 1.202 & 75 \\
\hline Florida & 0.675 & 1.154 & 1.131 & 0.300 & 0.547 & 2.525 & 67 \\
\hline Georgia & 0.713 & 1.128 & 1.142 & 0.258 & 0.567 & 2.107 & 159 \\
\hline
\end{tabular}




\begin{tabular}{|c|c|c|c|c|c|c|c|}
\hline Louisiana & 0.697 & 1.117 & 1.170 & 0.687 & 0.530 & 5.979 & 64 \\
\hline Mississippi & 0.435 & 0.774 & 0.733 & 0.151 & 0.389 & 1.095 & 82 \\
\hline North Carolina & 0.699 & 1.059 & 1.041 & 0.210 & 0.505 & 1.733 & 100 \\
\hline South Carolina & 0.791 & 1.248 & 1.219 & 0.215 & 0.689 & 1.755 & 46 \\
\hline Texas & 0.600 & 0.988 & 0.993 & 0.464 & 0.349 & 6.048 & 252 \\
\hline Kentucky & 0.662 & 1.003 & 1.005 & 0.192 & 0.527 & 1.786 & 120 \\
\hline Maryland & 0.783 & 1.103 & 1.214 & 0.192 & 0.767 & 1.537 & 24 \\
\hline Oklahoma & 0.574 & 0.816 & 0.810 & 0.158 & 0.461 & 1.295 & 77 \\
\hline Tennessee & 0.648 & 1.041 & 1.086 & 0.204 & 0.486 & 1.591 & 95 \\
\hline West Virginia & 0.693 & 1.010 & 0.999 & 0.169 & 0.686 & 1.380 & 55 \\
\hline \multicolumn{8}{|l|}{ MOUNTAIN } \\
\hline Arizona & 0.479 & 0.876 & 0.921 & 0.218 & 0.628 & 1.496 & 14 \\
\hline Colorado & 0.638 & 0.996 & 1.011 & 0.230 & 0.557 & 2.198 & 63 \\
\hline Idaho & 0.637 & 1.085 & 1.078 & 0.162 & 0.692 & 1.434 & 44 \\
\hline Montana & 0.600 & 1.079 & 1.104 & 0.328 & 0.654 & 3.152 & 56 \\
\hline Nevada & 0.693 & 1.245 & 1.275 & 0.355 & 0.969 & 2.222 & 17 \\
\hline New Mexico & 0.539 & 1.025 & 1.014 & 0.292 & 0.523 & 2.319 & 31 \\
\hline Utah & 0.598 & 0.988 & 1.091 & 0.205 & 0.767 & 1.603 & 27 \\
\hline Wyoming & 0.685 & 1.065 & 1.187 & 0.269 & 0.814 & 1.874 & 23 \\
\hline \multicolumn{8}{|l|}{ PACIFIC } \\
\hline California & 0.640 & 1.002 & 1.125 & 0.223 & 0.805 & 1.938 & 58 \\
\hline Oregon & 0.615 & 1.045 & 1.121 & 0.195 & 0.873 & 1.638 & 36 \\
\hline Washington & 0.612 & 0.974 & 1.007 & 0.159 & 0.663 & 1.349 & 39 \\
\hline Mean & 0.653 & 1.012 & & & & & \\
\hline Std. Dev. & 0.076 & 0.107 & & & & & \\
\hline
\end{tabular}

Source: See Appendix 1. The retail sales were adjusted for inflation using the CPI with $1967=1$. The ratios of per capita retail sales in the states are based on aggregated information for the state. For example, retail sales per capita in 1929 was calculated as total retail sales in 1929 divided by an estimate of total population in the state in 1929. Thus, the ratio reported here will differ from the average of the ratios for the counties within the state. The standard deviation, minimum, and maximum information are drawn from per capita retail sales for the counties within the state. 
Table 2

Per Capita New Deal Grants, March 1933 to June 1939:

State Values and Distributional Information for Counties within States (nominal dollars)

\begin{tabular}{|c|c|c|c|c|c|c|c|c|c|}
\hline & \multicolumn{4}{|c|}{ Public Works and Relief Grants } & \multicolumn{5}{|c|}{ AAA Grants } \\
\hline & $\begin{array}{c}\text { State } \\
\text { Value } \\
\end{array}$ & $\begin{array}{l}\text { Std. } \\
\text { Dev. }\end{array}$ & Max. & Min. & $\begin{array}{l}\text { State } \\
\text { Value }\end{array}$ & $\begin{array}{l}\text { Std. } \\
\text { Dev. }\end{array}$ & Max. & Min. & $\mathbf{N}$ \\
\hline \multicolumn{10}{|c|}{ NEW ENGLAND } \\
\hline Connecticut & 91.6 & 36.3 & 181.2 & 70.3 & 2.1 & 3.2 & 8.7 & 0.2 & 8 \\
\hline Maine & 102.4 & 120.0 & 518.1 & 55.9 & 1.5 & 2.0 & 8.3 & 0.2 & 16 \\
\hline Massachusetts & 130.3 & 111.3 & 532.3 & 98.0 & 0.5 & 3.2 & 9.1 & 0.0 & 14 \\
\hline New & & & & & & & & & \\
\hline Hampshire & 86.0 & 18.6 & 112.5 & 59.1 & 0.8 & 0.3 & 1.3 & 0.4 & 10 \\
\hline Rhode Island & 104.9 & 78.6 & 279.1 & 88.6 & 0.1 & 0.1 & 0.3 & 0.0 & 5 \\
\hline Vermont & 76.1 & 38.1 & 203.5 & 50.8 & 2.4 & 1.4 & 6.2 & 1.1 & 14 \\
\hline \multicolumn{10}{|c|}{ MID-ATLANTIC } \\
\hline Delaware & 111.1 & 28.3 & 122.7 & 69.3 & 5.6 & 5.5 & 13.6 & 2.8 & 3 \\
\hline New Jersey & 125.0 & 57.8 & 299.8 & 58.3 & 0.5 & 1.3 & 4.5 & 0.0 & 21 \\
\hline New York & 150.5 & 37.7 & 257.5 & 49.5 & 0.6 & 2.1 & 8.3 & 0.0 & 58 \\
\hline Pennsylvania & 134.6 & 34.5 & 215.2 & 55.6 & 1.1 & 2.7 & 16.1 & 0.0 & 67 \\
\hline \multicolumn{10}{|c|}{ EAST NORTH CENTRAL } \\
\hline Illinois & 133.3 & 45.0 & 248.8 & 32.6 & 12.7 & 25.6 & 122.9 & 0.1 & 102 \\
\hline Indiana & 115.8 & 50.7 & 270.4 & 29.3 & 18.7 & 21.1 & 106.4 & 1.0 & 92 \\
\hline Michigan & 116.2 & 82.4 & 412.5 & 51.7 & 5.0 & 8.6 & 32.2 & 0.1 & 83 \\
\hline Ohio & 140.2 & 44.6 & 278.1 & 47.0 & 7.5 & 17.8 & 68.5 & 0.0 & 88 \\
\hline Wisconsin & 126.8 & 71.0 & 454.9 & 43.1 & 11.5 & 12.7 & 56.6 & 0.1 & 71 \\
\hline \multicolumn{10}{|c|}{ WEST NORTH CENTRAL } \\
\hline Iowa & 72.3 & 26.9 & 147.8 & 21.4 & 64.7 & 31.5 & 150.5 & 9.6 & 99 \\
\hline Kansas & 100.8 & 35.6 & 276.9 & 39.2 & 81.8 & 183.3 & 936.1 & 0.6 & 105 \\
\hline Minnesota & 129.5 & 53.5 & 274.5 & 22.9 & 27.8 & 34.6 & 159.3 & 0.0 & 87 \\
\hline Missouri & 103.7 & 32.6 & 241.7 & 44.1 & 20.8 & 25.1 & 142.5 & 0.3 & 114 \\
\hline Nebraska & 102.4 & 41.4 & 267.2 & 12.3 & 74.2 & 87.2 & 584.9 & 2.9 & 93 \\
\hline North Dakota & 134.5 & 46.6 & 325.5 & 60.3 & 127.7 & 40.3 & 235.7 & 59.9 & 53 \\
\hline South Dakota & 159.4 & 51.8 & 408.8 & 67.9 & 100.3 & 48.9 & 267.3 & 12.1 & 68 \\
\hline \multicolumn{10}{|l|}{ SOUTH } \\
\hline Virginia & 81.4 & 86.5 & 762.2 & 16.2 & 6.3 & 6.1 & 26.8 & 0.1 & 100 \\
\hline Alabama & 68.9 & 24.5 & 136.7 & 23.6 & 19.5 & 10.4 & 51.8 & 0.4 & 67 \\
\hline Arkansas & 78.4 & 26.1 & 189.8 & 37.7 & 31.1 & 17.4 & 85.5 & 2.2 & 75 \\
\hline Florida & 108.1 & 73.6 & 410.6 & 38.0 & 4.1 & 20.7 & 126.2 & 0.0 & 67 \\
\hline Georgia & 64.8 & 70.0 & 871.1 & 19.2 & 18.0 & 12.9 & 47.1 & 0.0 & 159 \\
\hline Louisiana & 84.8 & 49.8 & 350.5 & 22.1 & 21.9 & 19.4 & 82.8 & 0.0 & 64 \\
\hline Mississippi & 62.0 & 27.7 & 152.4 & 24.7 & 28.0 & 15.4 & 64.2 & 0.1 & 82 \\
\hline North & & & & & & & & & \\
\hline Carolina & 53.7 & 32.3 & 206.7 & 21.0 & 17.5 & 13.5 & 63.7 & 0.1 & 100 \\
\hline
\end{tabular}




\begin{tabular}{lrrrrrrrrr} 
South & & & & & & & & \\
Carolina & 90.9 & 49.6 & 308.5 & 44.2 & 21.0 & 10.2 & 45.8 & 0.6 & 46 \\
Texas & 78.9 & 93.3 & 1189.7 & 9.3 & 37.5 & 106.3 & 852.1 & 0.0 & 252 \\
Kentucky & 74.1 & 41.2 & 405.9 & 23.5 & 17.6 & 19.1 & 87.5 & 0.0 & 120 \\
Maryland & 98.2 & 65.8 & 246.3 & 25.3 & 4.2 & 10.7 & 41.4 & 0.0 & 24 \\
Oklahoma & 101.3 & 69.5 & 590.1 & 44.4 & 38.5 & 79.2 & 440.8 & 1.7 & 77 \\
Tennessee & 63.0 & 28.4 & 214.1 & 18.6 & 14.4 & 15.9 & 103.4 & 0.5 & 95 \\
West Virginia & 108.7 & 44.7 & 291.3 & 44.5 & 1.6 & 3.1 & 19.7 & 0.1 & 55 \\
MOUNTAIN & & & & & & & & & \\
Arizona & 249.2 & 998.0 & 3948.2 & 122.3 & 10.6 & 13.6 & 40.3 & 0.1 & 14 \\
Colorado & 172.5 & 123.7 & 740.2 & 65.5 & 28.6 & 53.4 & 242.4 & 0.0 & 63 \\
Idaho & 145.0 & 62.0 & 316.8 & 77.2 & 46.8 & 58.3 & 249.1 & 0.0 & 44 \\
Montana & 215.0 & 90.0 & 493.1 & 79.3 & 72.8 & 86.4 & 380.1 & 0.0 & 56 \\
Nevada & 587.9 & 583.1 & 2721.3 & 187.0 & 5.3 & 8.2 & 25.6 & 1.1 & 17 \\
New Mexico & 176.7 & 138.7 & 789.5 & 86.8 & 23.9 & 37.3 & 135.3 & 0.8 & 31 \\
Utah & 163.3 & 103.7 & 594.7 & 94.8 & 13.6 & 19.6 & 100.1 & 2.1 & 27 \\
Wyoming & 213.9 & 86.6 & 421.2 & 127.3 & 31.2 & 39.1 & 153.7 & 1.1 & 23 \\
PACIFIC & & & & & & & & & \\
California & 140.8 & 171.6 & 1087.5 & 39.5 & 4.8 & 23.2 & 96.1 & 0.0 & 58 \\
Oregon & 122.3 & 121.0 & 734.8 & 39.8 & 16.0 & 102.5 & 489.6 & 0.1 & 36 \\
Washington & 157.2 & 87.7 & 499.0 & 48.8 & 16.5 & 91.3 & 350.1 & 0.0 & 39 \\
United States & & & & & & & & & \\
Average & 115.5 & 16.2 & & & & & & & \\
\hline
\end{tabular}

Notes: The state value is computed as total grants in the state from 1933 to 1939 divided by the population in 1930. The standard deviation, minimum, and maximum are drawn from per capita grants for the counties within the state. The mean per capita grant for the counties within each state will differ from the state value. AAA includes payments to farmers under the Agricultural Adjustment Act, including rental and benefit payments in 1934 and 1935 and Conservation payments in 1936 and 1937. Relief and Public Works includes spending under the Federal Emergency Relief Administration, the Civil Works Administration, the Works Projects Administration, the Social Security programs for Old-Age Assistance, Aid to the Blind, and Aid to Dependent Children, the Public Works Administration, the Public Buildings Administration, and the Public Roads Administration.

Sources: See Appendix 1. 
Table 3

OLS and 2SLS Estimates of the Impact of New Deal Grants on Retail Sales Growth Rate, 1929-1939

\begin{tabular}{|c|c|c|c|c|c|c|c|c|c|c|}
\hline \multirow{2}{*}{$\begin{array}{l}\text { Variables } \\
\text { Constant }\end{array}$} & \multicolumn{4}{|c|}{ Retail sales growth equations } & \multicolumn{4}{|c|}{$\begin{array}{c}\text { 2SLS } \\
\text { First-stage relief } \\
\text { and public } \\
\text { works equation } \\
\end{array}$} & \multicolumn{2}{|c|}{$\begin{array}{c}\text { First-stage AAA } \\
\text { equation }\end{array}$} \\
\hline & $\begin{array}{l}\text { Coeff. } \\
0.00765\end{array}$ & $\begin{array}{r}\text { t-stat. } \\
1.22\end{array}$ & $\begin{array}{l}\text { Coeff. } \\
-0.05431\end{array}$ & $\begin{array}{l}\text { t-stat. } \\
-0.18\end{array}$ & $\begin{array}{l}\text { Coeff. } \\
-0.32398\end{array}$ & $\begin{array}{l}\text { t-stat. } \\
-0.76\end{array}$ & $\begin{array}{l}\text { Coeff. } \\
-52.809\end{array}$ & $\begin{array}{l}\text { t-stat. } \\
-0.10\end{array}$ & $\begin{array}{l}\text { Coeff. } \\
-1624.3\end{array}$ & $\begin{array}{l}\text { t-stat. } \\
-4.80\end{array}$ \\
\hline $\begin{array}{l}\text { Endogenous Variables: } \\
\text { Per capita public works and } \\
\text { relief spending } \\
\text { Per capita AAA spending }\end{array}$ & $\begin{array}{l}0.000046 \\
-0.00025\end{array}$ & $\begin{array}{r}3.13 \\
-15.3\end{array}$ & $\begin{array}{r}0.000023 \\
-0.00004\end{array}$ & $\begin{array}{r}1.55 \\
-1.96\end{array}$ & $\begin{array}{r}0.00082 \\
-0.00008\end{array}$ & $\begin{array}{r}3.25 \\
-0.41\end{array}$ & & & & \\
\hline $\begin{array}{l}\text { Instrumental Variables: } \\
\text { Standard deviation of } \\
\text { Democratic voting, 1896- } \\
1928\end{array}$ & & & & & & & 4.4066 & 3.02 & -0.2427 & -0.25 \\
\hline $\begin{array}{l}\text { Voter turnout, } 1928 \\
\text { County land area } \\
\text { Latitude } \\
\text { Longitude } \\
\text { Membership in religious } \\
\text { denomination as a pct. of } \\
\text { population, } 1926\end{array}$ & & & & & & & $\begin{array}{l}0.4084 \\
0.0097 \\
3.4117 \\
2.2790\end{array}$ & $\begin{array}{l}0.35 \\
1.78 \\
0.62 \\
0.81\end{array}$ & $\begin{array}{r}1.4191 \\
-0.0045 \\
13.2776 \\
14.8241\end{array}$ & $\begin{array}{r}1.83 \\
-1.26 \\
3.66 \\
7.97\end{array}$ \\
\hline \multicolumn{11}{|l|}{ Exogenous Variables: } \\
\hline $\begin{array}{l}\text { Retail sales per capita, } 1929 \\
\text { County has access to river } \\
\text { flowing through } 11-20 \\
\text { counties }\end{array}$ & & & -0.00052 & -19.6 & -0.00045 & -8.35 & -0.0833 & -2.57 & 0.1359 & 6.39 \\
\hline
\end{tabular}


County has access to river

flowing through 21-50

counties

County has access to river

flowing through more than 50 counties

Pct. of population black, 1930

Pct. of population living in

urban area, 1930

Pct. of county's land in farms,

1929

$\begin{array}{rrrrrrrr}-0.01449 & -1.36 & -0.0345 & -2.14 & 28.8922 & 2.22 & 9.2668 & 1.08 \\ & & & & & & & \\ -0.02467 & -1.91 & -0.04722 & -2.40 & 35.8010 & 2.26 & 19.6844 & 1.89 \\ 0.000508 & 1.25 & 0.00144 & 2.19 & -1.2386 & -2.39 & 1.1554 & 3.39 \\ 0.002260 & 8.86 & 0.00232 & 3.44 & -0.0045 & -0.01 & -2.7879 & -13.8 \\ 0.000552 & 0.37 & 0.00358 & 1.49 & -3.1857 & -1.74 & 4.3143 & 3.57 \\ & & & & & & & \\ -0.00038 & -0.57 & -0.00006 & -0.06 & -0.5491 & -0.68 & -1.1912 & -2.23 \\ -0.00358 & -2.54 & -0.00128 & -0.61 & -2.0635 & -1.18 & -1.7630 & -1.53 \\ 0.001070 & 0.95 & 0.00308 & 1.80 & -1.5199 & -1.04 & -1.2789 & -1.33\end{array}$

Pct. of population

manufacturing workers, 1929

Pct. of population foreign

born, 1930

Pct. of population illiterate,

1930

$\begin{array}{lll}0.001070 & 0.95 & 0.00308\end{array}$

Pct. of population in the following age categories, 1930:

$\begin{array}{llllllllll}10-19 & 0.000447 & 0.08 & 0.00398 & 0.50 & -3.7407 & -0.55 & 6.6792 & 1.51 \\ 20-29 & 0.006260 & 1.49 & -0.01046 & -1.33 & 20.3294 & 3.97 & -2.5304 & -0.75 \\ 30-34 & 0.008870 & 0.81 & 0.03756 & 2.11 & -34.610 & -2.59 & 0.5877 & 0.07 \\ 35-44 & 0.017850 & 2.91 & 0.00100 & 0.10 & 19.5177 & 2.61 & 7.6085 & 1.55 \\ 45-54 & 0.016310 & 2.52 & 0.01114 & 1.19 & 5.6567 & 0.71 & 6.9719 & 1.34 \\ 55-64 & 0.003910 & 0.45 & -0.0200 & -1.39 & 27.4797 & 2.57 & -12.8080 & -1.82 \\ \text { Over 64 } & 0.001350 & 0.21 & 0.01910 & 1.72 & -20.624 & -2.57 & -19.8995 & -3.77\end{array}$


Population growth rate, 1920-

1930

Average monthly

temperature, 1930-1940

Average monthly

precipitation, 1930-1940

\begin{tabular}{|c|c|c|c|c|c|c|c|}
\hline 0.089730 & 5.29 & 0.13725 & 4.87 & -77.486 & -3.64 & -1.2055 & -0.09 \\
\hline-0.00268 & -1.23 & 0.00287 & 0.82 & -5.2042 & -1.55 & 5.5210 & 2.50 \\
\hline-0.00265 & -0.20 & -0.01181 & -0.55 & 16.5756 & 0.99 & -55.8806 & -5 . \\
\hline 0.000498 & 0.57 & 0.00051 & 0.37 & -0.3187 & -0.30 & -3.5098 & -5 \\
\hline 0.003320 & 1.77 & -0.01154 & -2.16 & 18.3419 & 7.98 & 0.9012 & 0.6 \\
\hline 0.000031 & 1.10 & $-9.7 \times 10^{-6}$ & -0.24 & 0.0425 & 1.24 & -0.0471 & -2 \\
\hline-0.00059 & -2.87 & -0.00036 & -1.16 & -0.3042 & -1.21 & -0.3475 & -2 . \\
\hline-0.00002 & -2.03 & -0.00003 & -1.60 & 0.0119 & 0.85 & 0.0480 & 5. \\
\hline-0.00007 & -2.78 & 0.00006 & 1.06 & -0.1540 & -5.15 & -0.0368 & 1 \\
\hline-0.04519 & -1.30 & -0.07772 & -0.57 & 65.1480 & 1.71 & 672.18 & 2 \\
\hline-0.00001 & -1.98 & -0.00003 & -2.29 & 0.0170 & 2.14 & -0.0310 & -5 . \\
\hline 0.000013 & 2.06 & 0.00002 & 2.09 & -0.0126 & -1.58 & 0.0277 & 5. \\
\hline-0.00011 & -0.30 & -0.00527 & -3.10 & & 15.5 & -0.0046 & -0. \\
\hline 0.000082 & 0.96 & 0.00030 & 2.17 & -0.3172 & -2.98 & 0.0353 & 0 \\
\hline 0.001270 & 0.83 & 0.00596 & 2.31 & -5.5774 & -3.00 & -0.7480 & 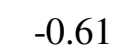 \\
\hline
\end{tabular}

Months of excess or severe

drought, 1930-1940

0.00049

$0.57 \quad 0.00051$

0.37

$-0.3187$

$-0.30$

$-3.5098$

$-5.06$

Months of excess or severe

wetness, 1930-1940

Pct. of county's land in farms

$\mathrm{x}$ average temperature

Pct. of county's land in farms

$\mathrm{x}$ average precipitation

Pct. of county's land in farms

$\mathrm{x}$ months of excess or severe

drought

Pct. of county's land in farms

$\mathrm{x}$ months of excess or severe

wetness

\begin{tabular}{|c|c|c|c|c|c|c|c|}
\hline 0.089730 & 5.29 & 0.13725 & 4.87 & -77.486 & -3.64 & -1.2055 & -0.09 \\
\hline-0.00268 & -1.23 & 0.00287 & 0.82 & -5.2042 & -1.55 & 5.5210 & 2.50 \\
\hline-0.00265 & -0.20 & -0.01181 & -0.55 & 16.5756 & 0.99 & -55.8806 & -5 . \\
\hline 0.000498 & 0.57 & 0.00051 & 0.37 & -0.3187 & -0.30 & -3.5098 & -5 \\
\hline 0.003320 & 1.77 & -0.01154 & -2.16 & 18.3419 & 7.98 & 0.9012 & 0.6 \\
\hline 0.000031 & 1.10 & $-9.7 \times 10^{-6}$ & -0.24 & 0.0425 & 1.24 & -0.0471 & -2 \\
\hline-0.00059 & -2.87 & -0.00036 & -1.16 & -0.3042 & -1.21 & -0.3475 & -2 . \\
\hline-0.00002 & -2.03 & -0.00003 & -1.60 & 0.0119 & 0.85 & 0.0480 & 5. \\
\hline-0.00007 & -2.78 & 0.00006 & 1.06 & -0.1540 & -5.15 & -0.0368 & 1 \\
\hline-0.04519 & -1.30 & -0.07772 & -0.57 & 65.1480 & 1.71 & 672.18 & 2 \\
\hline-0.00001 & -1.98 & -0.00003 & -2.29 & 0.0170 & 2.14 & -0.0310 & -5 . \\
\hline 0.000013 & 2.06 & 0.00002 & 2.09 & -0.0126 & -1.58 & 0.0277 & 5. \\
\hline-0.00011 & -0.30 & -0.00527 & -3.10 & & 15.5 & -0.0046 & -0. \\
\hline 0.000082 & 0.96 & 0.00030 & 2.17 & -0.3172 & -2.98 & 0.0353 & 0 \\
\hline 0.001270 & 0.83 & 0.00596 & 2.31 & -5.5774 & -3.00 & -0.7480 & 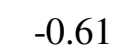 \\
\hline
\end{tabular}

"Dustbowl" County

Elevation range

Maximum elevation

Number of bays

Number of lakes

Number of beaches

0.001270 


\begin{tabular}{|c|c|c|c|c|c|c|c|c|c|}
\hline \multicolumn{2}{|l|}{ Number of swamps } & 0.000595 & 1.11 & 0.00204 & 2.34 & -1.9258 & -2.96 & -0.1942 & -0.45 \\
\hline Atlantic Coast county & & -0.01135 & -0.47 & 0.05196 & 1.30 & 80.3457 & -2.69 & 45.7678 & 2.33 \\
\hline Pacific Coast county & & -0.08052 & -1.95 & -0.0731 & -1.27 & 18.3206 & -0.36 & -38.1928 & -1.14 \\
\hline Gulf Coast county & & 0.132980 & 4.30 & 0.22373 & 4.24 & 99.5422 & -2.61 & 57.7780 & 2.30 \\
\hline Great Lake county & & 0.002400 & 0.09 & 0.00839 & 0.22 & -3.6799 & -0.11 & -1.1560 & -0.05 \\
\hline $\begin{array}{l}\text { State fixed effects } \\
\mathrm{R}^{2} \\
\text { Adjusted } \mathrm{R}^{2} \\
\mathrm{~N}\end{array}$ & $\begin{array}{l}\text { Excl } \\
\text { uded } \\
0.075 \\
0.007 \\
3,060\end{array}$ & $\begin{array}{l}\text { Included } \\
0.412 \\
0.395 \\
3,060\end{array}$ & & $\begin{array}{r}\text { Included } \\
0.266 \\
0.245 \\
3,060\end{array}$ & & $\begin{array}{r}\text { Included } \\
0.388 \\
0.371 \\
3,060\end{array}$ & & $\begin{array}{r}\text { Included } \\
0.659 \\
0.648 \\
3,060\end{array}$ & \\
\hline
\end{tabular}

Notes: The dependent variable in the "retail sales growth equations" is the difference in the logged values of per capita retail sales between 1939 and 1929. Summary statistics of the variables are reported in Appendix Table 1.

Sources: See Appendix 1. 
Table 4

Summary of the Impact of New Deal Grants on the Retail Sales Growth Rates: 1929-1939, 19291935, and 1933-1939

\begin{tabular}{lll}
\hline Coefficient t-stat. & $\begin{array}{l}\text { OSD } \\
\text { effect }\end{array}$ & $\begin{array}{l}\text { Impact on } \\
\text { retail sales } \\
\text { from one } \\
\text { follarst-stage }\end{array}$ \\
& increase in \\
& New Deal \\
& spending \\
\hline
\end{tabular}

Panel A: 1929-1939

OLS, only New Deal as correlates

Public works and relie

AAA

OLS, all correlates

Public works and relief

AAA

2SLS, all correlates

Public works and relief

AAA

$\begin{array}{lll}-0.000080 & -0.41 \quad-0.09\end{array}$

$\begin{array}{lll}-0.000254 & -15.31 & -0.27\end{array}$

$\begin{array}{lll}0.000023 & 1.55 & 0.03\end{array}$

$\begin{array}{lll}-0.000044 & -1.96 & -0.05\end{array}$

$\begin{array}{lll}0.000817 & 3.25 & 0.97\end{array}$
Panel B: 1929-1935

OLS, only New Deal as correlates

Public works and relief

AAA

OLS, all correlates

Public works and relief

AAA

0.000110

0.000128

$-0.000256$

4.01

$-7.09$

0.07

$-0.13$

$\begin{array}{ll}1.26 & 0.02\end{array}$

$2.31 \quad 0.05$

2SLS (Instruments exclude latitude

Public works and relief

$$
0.001000
$$

2.71

0.56

AAA

$\begin{array}{lll}-0.000420 & -0.41 & -0.21\end{array}$

Panel C: 1933-1939

OLS, only New Deal as correlates

Public works and relief

AAA

0.000035

$-0.000033$

2.75

0.03

0.05

$-0.04$

0.000009

0.64

$-0.000025$

$-1.22$

0.01

$-0.03$

$\begin{array}{llll}\text { Public works and relief } & 0.000638 & 3.08 & 0.91\end{array}$

\begin{tabular}{|c|c|c|}
\hline \multirow{2}{*}{$\begin{array}{l}\text { Public works and relief } \\
\text { AAA }\end{array}$} & 0.000009 & \\
\hline & -0.000025 & -1.22 \\
\hline
\end{tabular}

2SLS
$\$ 0.02$

$-0.14$

0.01

$-0.02$

0.44 volatility 3.02 , turnout 0.35 , area 1.78 , latitude 0.62 , longitude 0.81 , church -2.95

-0.04 volatility -0.25 , turnout 1.83 , area -1.26 , latitude 3.66 , longitude 7.97 , church -0.02

0.34 volatility 3.09 , turnout 0.30 , area 1.73 , latitude 0.60 ,

longitude 0.64 , church -3.19 volatility 3.83 , turnout 1.31 , area 4.03 , church -2.75

-0.22 volatility 0.12 , turnout 2.31 , area -1.86 , church 0.28

0.02

$-0.02$

0.00

$-0.01$ 

AAA
0.000005
0.03
0.01

0.00 volatility -0.45 , turnout 2.04 , area -0.95 , latitude 3.65 , longitude 8.15 , church 0.27

Notes: The impact of a dollar increase in New Deal spending on per capita retail sales was calculated at the sample mean level of retail sales from 1939 ( $\$ 533.54 ; 1967$ dollars).

The instruments are land area in square miles (area), the standard deviation of the percent voting Democrat for president from 1896 to 1928 (volatility), the number of votes cast in the 1928 presidential election divided by the population in 1930 (turnout), latitude, longitude, and church membership in 1926 as a percentage of the population in 1930 (church).

Panel A results are drawn from Table 3, 2SLS results in Panels B and C are reported in Appendix Table 2. The regressions underlying Panels C and D use the same set of independent variables as the 1929-1939 difference regression.

Specifications with all correlates include the list of independent variables and state dummies listed in Table 3 for 1929-1939. In the specification for 1929-1935, latitude and longitude are included in both the first and second stages, see Appendix Table 2 for full results. In the specification for 1933-1939 retail sales per capita in 1933 replaces retail sales per capita in 1929. See Appendix Table 2 for full results.

Sources: See Appendix 1. 


\section{Appendix Table 1}

Sample Means and Standard Deviations of Variables in Analysis (3,062 counties)

\begin{tabular}{|c|c|c|}
\hline Variables & Mean & Std Dev \\
\hline Growth Rate in Per Capita Retail Sales (1967\$), 1929-1935 & -0.020 & 0.241 \\
\hline Growth Rate in Per Capita Retail Sales (1967\$), 1929-1940 & -0.226 & 0.247 \\
\hline Growth Rate in Per Capita Retail Sales (1967\$), 1933-1939 & 0.453 & 0.200 \\
\hline Public Works and Relief Grants from 1933-1939 in 1967\$ over 1930 & & \\
\hline Population & 261.487 & 288.011 \\
\hline Estimate of AAA Grants from 1933-1939 in $1967 \$$ over 1930 Population & 157.576 & 253.682 \\
\hline Std. Deviation of Percent Voting Democrat for President, 1896-1928 & 10.228 & 4.947 \\
\hline Presidential Voters in 1928 over Population in 1930 & 27.479 & 14.283 \\
\hline Land Area of County In Square Miles & 968.162 & 1314.820 \\
\hline Latitude of County Seat & 38.090 & 4.859 \\
\hline Longitude of County Seat & 91.605 & 11.447 \\
\hline Church Members in 1926 as percent of Population as of 1930 & 48.245 & 23.895 \\
\hline Retail Sales per Capita in 1929 in $1967 \$$ & 541.258 & 269.742 \\
\hline County has access to river flowing through $11-20$ counties & 0.239 & 0.451 \\
\hline County has access to river flowing through $21-50$ counties & 0.140 & 0.376 \\
\hline County has access to river flowing through more than 50 counties & 0.092 & 0.294 \\
\hline Percent Black, 1930 & 11.105 & 18.346 \\
\hline Percent Urban, 1930 & 20.963 & 24.821 \\
\hline Percent of Land on Farms 1929 & 64.506 & 27.336 \\
\hline Manufacturing Workers in 1929 as percentage of adult population in 1930 & 5.545 & 7.366 \\
\hline Percent Foreign-Born, 1930 & 4.731 & 5.898 \\
\hline Percent Illiterate, 1930 & 5.413 & 5.831 \\
\hline Percent aged 10-19, 1930 & 21.009 & 2.737 \\
\hline Percent aged 20-29, 1930 & 15.714 & 2.074 \\
\hline Percent aged 30-34, 1930 & 6.420 & 0.928 \\
\hline Percent aged 35-44, 1930 & 12.351 & 1.726 \\
\hline Percent aged 45-54, 1930 & 10.021 & 1.599 \\
\hline Percent aged 55-64, 1930 & 6.794 & 1.814 \\
\hline Percent aged 65 and up, 1930 & 5.782 & 2.204 \\
\hline Population Growth Rate, 1920-1930 & 0.075 & 0.280 \\
\hline Average Daily Temperature, 1930s & 55.076 & 8.176 \\
\hline Average Monthly Precipitation, 1930s & 2.920 & 1.123 \\
\hline Months of Extreme or Severe Drought, 1930s & 22.794 & 16.890 \\
\hline Months of Extreme or Severe Wet, 1930s & 3.448 & 5.260 \\
\hline Average Daily Temperature, 1930s x Percent of Land on Farms & 3539.490 & 1530.930 \\
\hline Average Monthly Precipitation, 1930s x Percent of Land on Farms & 183.876 & 92.748 \\
\hline Months of Extreme or Severe Drought, 1930s x Percent of Land on Farms & 1588.030 & 1501.620 \\
\hline Months of Extreme or Severe Wet, 1930s x Percent of Land on Farms & 221.574 & 404.254 \\
\hline "Dust Bowl" County & 0.016 & 0.126 \\
\hline
\end{tabular}


Range of Elevation

Maximum Elevation

Number of Bays

Number of Lakes

Number of Beaches

Number of Swamps

Coastal Access to Atlantic Ocean

Coastal Access to Pacific Ocean

Coastal Access to Gulf of Mexico

Coastal Access to Great Lakes
$1518.400 \quad 2355.750$

$2398.870 \quad 2959.420$

$3.045 \quad 13.947$

$21.010 \quad 55.304$

$0.498 \quad 3.147$

$2.386 \quad 8.070$

$0.043 \quad 0.204$

$0.013 \quad 0.115$

$0.017 \quad 0.130$

$0.027 \quad 0.162$

Sources: See Appendix 1. 


\section{Appendix Table 2}

2SLS Regression Results of Growth Rate in Per Capita Retail Sales (1967 \$) from 1929 to 1935 and 1933 to 1939

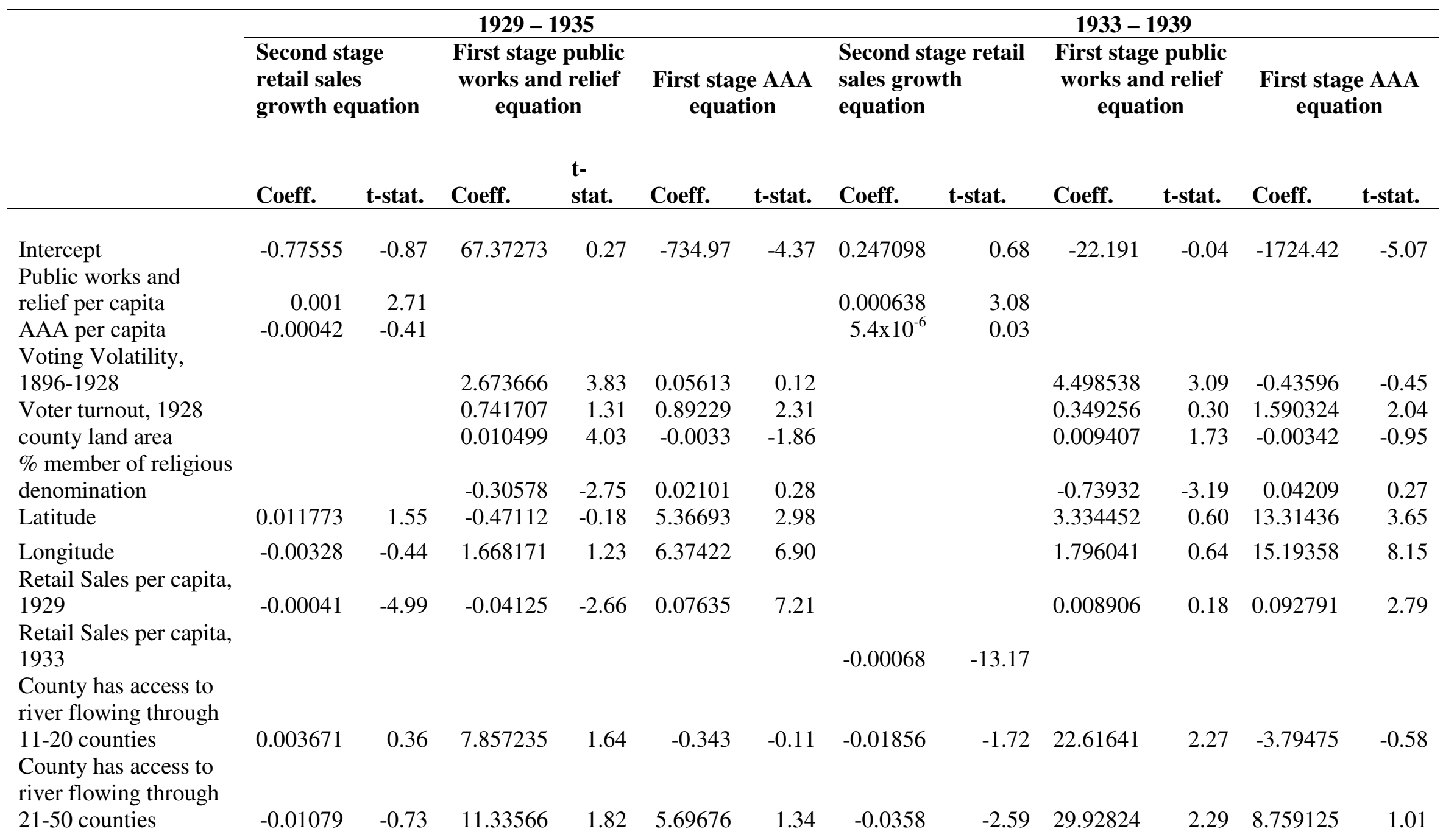


County has access to river flowing through more than 50 counties $\%$ black, 1930

$\%$ urban, 1930

$\%$ of land on farms, 1929

$\%$ of manufacturing workers, 1929

$\%$ foreign born, 1930

$\%$ illiterate, 1930

$\%$ aged $10-19,1930$

$\%$ aged $20-29,1930$

$\%$ aged $30-34,1930$

$\%$ aged $35-44,1930$

$\%$ aged $45-54,1930$

$\%$ aged 55-64, 1930

$\%$ aged 65 up, 1930

Population growth

rate, 1920-1930

Average monthly

temp., 1930-1940

Average monthly

precipitation, 1930-

1940

Months of excess or

severe drought, 1930-

1940

Months of excess or

severe wetness, 1930-

1940

\%farmland $\mathrm{x}$ average

temperature

$\%$ farmland $\mathrm{x}$ average

precipitation

\begin{tabular}{|c|c|c|c|c|c|c|c|c|c|c|c|}
\hline-0.01287 & -0.63 & 12.30629 & 1.62 & 10.5463 & 2.04 & -0.06935 & -4.08 & 40.36664 & 2.55 & 14.90563 & 1.43 \\
\hline 0.000477 & 0.77 & -0.1517 & -0.61 & 0.491 & 2.89 & 0.001029 & 1.83 & -1.31693 & -2.54 & 1.224022 & 3.57 \\
\hline 0.001891 & 1.28 & -0.28643 & -1.95 & -1.3217 & -13.20 & 0.002172 & 4.11 & -0.36849 & -1.18 & -2.45686 & -11.94 \\
\hline 0.001322 & 0.57 & -0.17027 & -0.19 & 1.41186 & 2.36 & 0.001265 & 0.63 & -3.06432 & -1.67 & 4.299685 & 3.54 \\
\hline-0.00137 & -1.35 & -0.35404 & -0.91 & -0.5463 & -2.06 & -0.00009 & -0.11 & -0.44637 & -0.55 & -1.25436 & -2.33 \\
\hline-0.00332 & 1.82 & 0.911122 & 1.08 & -0.7849 & -1.37 & -0.00041 & -0.23 & -1.83901 & -1.05 & -1.88145 & -1.62 \\
\hline 0.004599 & 2.58 & -1.69274 & -2.40 & -0.3888 & -0.81 & 0.000155 & 0.11 & -0.9442 & -0.65 & -1.70574 & -1.77 \\
\hline 0.004093 & 0.52 & -4.27337 & -1.32 & 4.59346 & 2.08 & 0.002918 & 0.43 & -3.22745 & -0.48 & 7.811161 & 1.76 \\
\hline-0.00649 & -0.92 & 14.24842 & 5.78 & -1.4977 & -0.89 & -0.0055 & -0.86 & 19.01379 & 3.72 & -0.78164 & -0.23 \\
\hline 0.036536 & 2.41 & -20.4177 & -3.17 & 2.58421 & 0.59 & 0.027443 & 1.80 & -35.8563 & -2.68 & 0.821027 & 0.09 \\
\hline 0.011948 & 1.28 & 4.390258 & 1.21 & 4.13337 & 1.67 & -0.00497 & -0.59 & 17. & 2.33 & 302 & 2.09 \\
\hline 0.008133 & 0.94 & 2.300388 & 0.61 & 2.53153 & 0.98 & 0.009936 & 1.24 & 3.811938 & 0.48 & 531 & 1.65 \\
\hline-0.02316 & -1.91 & 13.22558 & 2.58 & -6.1569 & -1.76 & -0.02699 & -2.19 & 29.06442 & 2.72 & -14.5397 & -2.06 \\
\hline 0.022856 & 1.73 & -10.3477 & -2.69 & -8.6212 & -3.29 & 0.018187 & 1.91 & -21.7478 & -2.72 & -17.9936 & -3.40 \\
\hline 0.047048 & 1.89 & -37.9903 & -3.73 & -2.7526 & -0.40 & 0.147998 & 6.10 & -80.8998 & -3.82 & 5.754492 & 0.41 \\
\hline 0.00338 & 0.84 & -3.71532 & -2.31 & 2.55002 & 2.32 & 0.003286 & 1.11 & -4.95641 & -1.47 & 5.399119 & 2.43 \\
\hline-0.00576 & -0.20 & 9.180476 & 1.15 & -25.307 & -4.64 & -0.01274 & -0.70 & 17.95302 & 1.08 & -54.8219 & -4.98 \\
\hline 0.000168 & 0.07 & 0.296546 & 0.59 & -2.0413 & -5.93 & -0.00051 & -0.44 & -0.22717 & -0.22 & -3.54612 & -5.12 \\
\hline-0.00445 & -0.88 & 11.15612 & 10.13 & 0.57292 & 0.76 & -0.01158 & -2.61 & 18.32863 & 7.96 & 0.757832 & 0.50 \\
\hline 0.000012 & 0.36 & 0.013471 & 0.82 & -0.0055 & -0.49 & 0.000013 & 0.36 & 0.03762 & 1.10 & -0.0419 & -1.8 \\
\hline-0.00034 & -0.80 & -0.25495 & -2.12 & -0.2686 & -3.27 & -0.00016 & -0.62 & -0.2575 & -1.03 & -0.42144 & \\
\hline
\end{tabular}




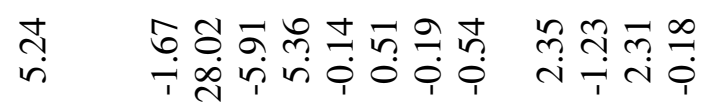

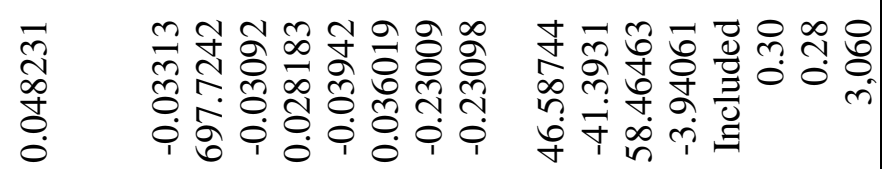

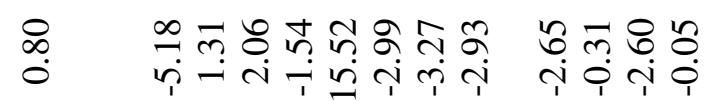

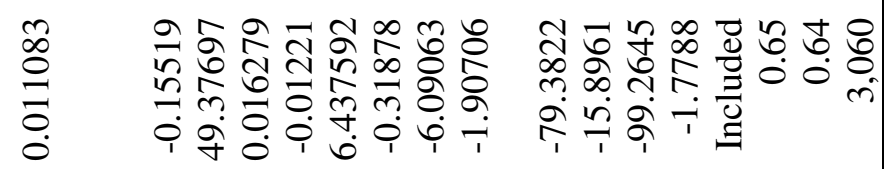

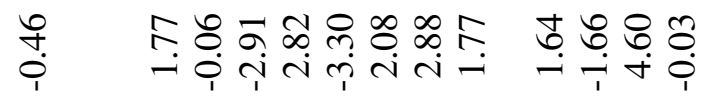

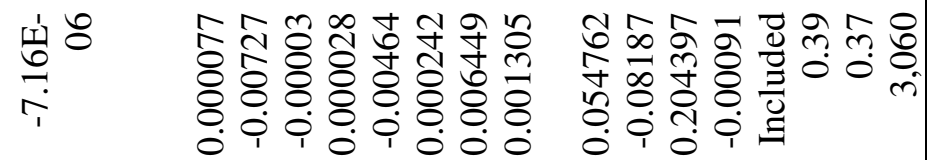

तु

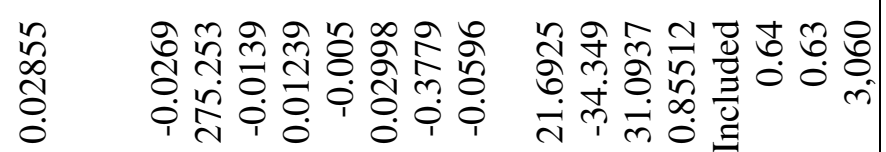

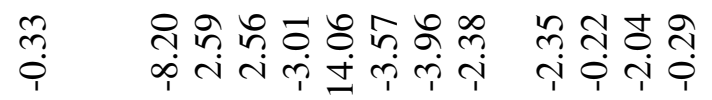

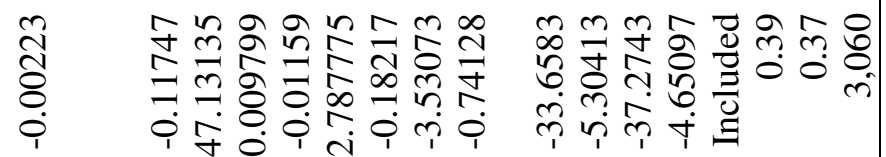

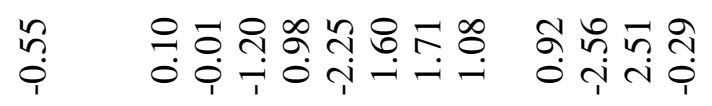

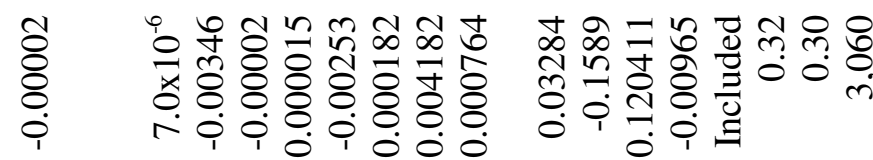

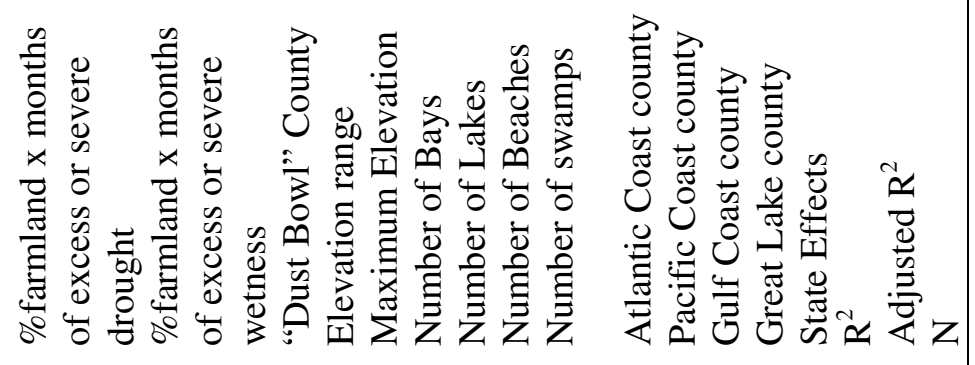




\section{Appendix Table 3}

2SLS Results for the Growth Rate of Retail Sales with Alternative Sets of Instrument: 1929-1939, 1929-1935, 1933-1939

\begin{tabular}{|c|c|c|c|c|c|c|}
\hline Specifications & Coeff. & $\begin{array}{l}\text { t- } \\
\text { stat. }\end{array}$ & $\begin{array}{l}\text { OSD } \\
\text { effect }\end{array}$ & $\begin{array}{l}\text { Impact } \\
\text { on retail } \\
\text { sales } \\
\text { from a } \\
\text { one } \\
\text { dollar } \\
\text { increase } \\
\text { in New } \\
\text { Deal } \\
\text { spending }\end{array}$ & t-statistics of instruments in first-stage & $\begin{array}{l}\text { Instruments } \\
\text { Correlated } \\
\text { with } \\
\text { second- } \\
\text { stage error? }\end{array}$ \\
\hline
\end{tabular}

Panel A: 1929-1939

Instruments include area, volatility, turnout, latitude, longitude, church

$\begin{array}{llllll}\text { Public works and } & 0.000817 & 3.25 & 0.97 & 0.44 & \text { volatility } 3.02 \text {, turnout } 0.35 \text {, area } 1.78,\end{array}$

relief latitude 0.62 , longitude 0.81 , church -2.95

AAA $\quad-0.00008-0.41 \quad-0.09 \quad-0.04$ volatility -0.25 , turnout 1.83 , area -1.26 ,

latitude 3.66, longitude 7.97 church -0.02

Instruments include area, volatility, turnout, latitude, longitude, church, invpop20

$\begin{array}{llllll}\text { Public works and } & 0.000750 & 3.46 & 0.89 & 0.40 & \text { volatility } 2.82 \text {, turnout } 0.15 \text {, area } 1.89,\end{array}$

relief

latitude 0.64 , longitude 0.78 , church -

2.91, invpop20 2.16

AAA $\quad-0.00006-0.33 \quad-0.06 \quad-0.03$ volatility -0.16 , turnout 1.91 , area -1.31 ,

latitude 3.65 , longitude 7.99 , church -

0.04 , invpop20 - 1.05

Instruments include area, volatility, turnout, latitude, longitude, church, invpop20, mean 9628

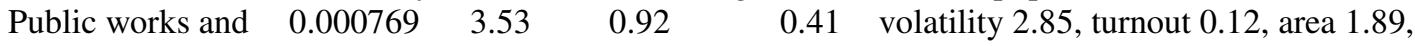

relief

latitude 0.64 , longitude 0.81 , church -

2.86, invpop20 2.17, mean9628 -0.46

AAA $\quad-0.00007 \quad-0.39 \quad-0.07 \quad-0.04$ volatility -0.21 , turnout 1.95 , area -1.30 ,

latitude 3.64 , longitude 7.90 , church -

0.10 , invpop20 -1.06, mean9628 0.65

Instruments include area, volatility, turnout, latitude, longitude, church, invpop20, prdem32

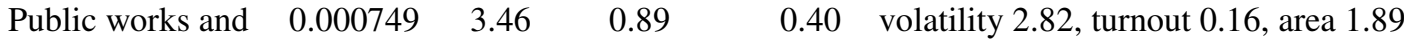

relief

latitude 0.63 , longitude 0.77 , church -

2.90, invpop20 2.15, prdem32 0.10

AAA $\quad-0.00011 \quad-0.62 \quad-0.12 \quad-0.06$ volatility -0.23 , turnout 2.04 , area -1.27 ,

latitude 3.64 , longitude 7.83 , church -

0.29 , invpop20 -1.11, prdem32 1.62

Instruments include area, volatility, turnout, latitude, longitude

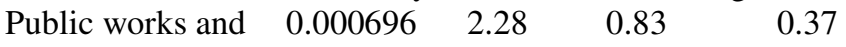

relief

$\begin{array}{llll}-0.00006 & -0.36 & -0.06 & -0.03\end{array}$

volatility 2.69 , turnout -0.10 , area 1.76 ,

latitude 0.66 , longitude 0.86

AAA $\quad-0.00006-0.36 \quad-0.06 \quad-0.03$ volatility -0.26 , turnout 1.84 , area -1.26 ,

latitude 3.66, longitude 7.97

Instruments include volatility, turnout, latitude, longitude, church

Public works and $0.000906 \quad 3.10 \quad 1.08 \quad 0.48$

relief

$\begin{array}{lllll}\text { AAA } & -0.00011 & -0.54 & -0.12 & -0.06\end{array}$

volatility 3.08 , turnout 0.19 , latitude 0.62 , no

longitude 0.82 , church -2.94

nstruments include area, turnout, latitude, longitude, church

, 0.29 , turnout 1.94 , latitude

3.66 , longitude 7.96 , church -0.03 
Public works and $\quad 0.000776 \quad 2.36 \quad 0.93$ relief

AAA
0.41 turnout -0.10 , area 1.88 , latitude 0.63 , longitude 1.03 , church -2.58

-0.05 turnout 1.88 , area -1.27 , latitude 3.66 , longitude 7.97 , church -0.06

Instruments include area, volatility, turnout, church

$\begin{array}{llll}\text { Public works and } & 0.000863 & 3.13 & 1.03\end{array}$ relief

AAA

0.46 volatility 3.07 , turnout 0.31 , area 1.79 , church -2.98

0.17 volatility 0.14 , turnout 1.54 , area -1.20 , church -0.22

Instruments include area, volatility, latitude, longitude, church

$\begin{array}{lllll}\text { Public works and } & 0.000817 & 3.25 & 0.97 & 0.44\end{array}$ relief

AAA

$\begin{array}{lll}-0.00008 & -0.39 & -0.09\end{array}$

Instruments include area, volatility, church

Public works and 0.000940

relief

AAA

$0.001076 \quad 0.60 \quad 1.15$

Instruments include turnout, latitude, longitude

Public works and $0.000637 \quad 0.57 \quad 0.76$

relief

AAA

$\begin{array}{lll}-0.00008 & -0.28 & -0.09\end{array}$
$-0.04$ volatility 3.00 , area 1.76 , latitude 0.60 , longitude 0.80 , church -2.93

volatility -0.52 , area -1.42 , latitude 3.57 , longitude 7.95 church 0.25

no

西

no

Panel B: 1929-1935

Instruments include area, volatility, turnout, latitude, longitude, church

$\begin{array}{llllll}\text { Public works and } & 0.000898 & 2.77 & 0.51 & 0.48 & \text { volatility } 3.83, \text { turnout } 1.31, \text { area } 4.03, \quad \text { yes }\end{array}$ relief latitude-0.18, longitude 1.23, church -2.75

AAA $\quad-0.00048 \quad-1.32 \quad-0.24 \quad-0.26 \quad$ volatility 0.12 , turnout 2.31 , area -1.86 , latitude 2.98, longitude 6.90 church 0.28

Instruments include area, volatility, turnout, church (latitude and longitude in final stage)
Public works and $0.001000 \quad 2.71 \quad 0.56 \quad 0.53$ volatility 3.83, turnout 1.31, area 4.03,
relief
church -2.75

AAA

$$
-0.00042 \quad-0.41 \quad-0.21
$$

-0.22 volatility 0.12 , turnout 2.31 , area -1.86 , church 0.28

Instruments include area, turnout, church (latitude and longitude in final stage)
0.00056
$1.11 \quad 0.32$
0.30
turnout 0.77 , area 4.15 , church -2.30
no

Public
relief

AAA

$\begin{array}{lll}-0.00097 & -0.88 & -0.48\end{array}$

-0.52 turnout 2.32, area -1.86 , church 0.29

Instruments include volatility, turnout, church (latitude and longitude in final stage)

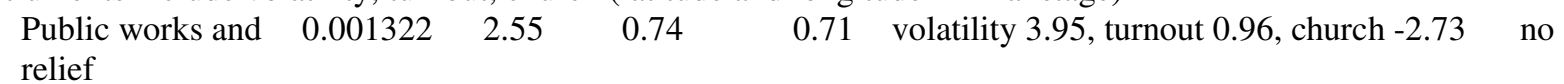

AAA $\quad-0.00111-0.82 \quad-0.55 \quad-0.59 \quad$ volatility 0.06 , turnout 2.48 , church 0.27

Instruments include area, volatility, turnout (latitude and longitude in final stage)
Public
relief
$\begin{array}{lll}0.000979 & 2.37 \quad 0.55\end{array}$
0.52 volatility 3.52 , turnout 0.91 , area 4.02
no

AAA $\quad-0.00044-0.42 \quad-0.22 \quad-0.23$ volatility 0.15 , turnout 2.38 , area -1.86

Instruments include area, volatility, church (latitude and longitude in final stage)

$\begin{array}{lcccccc}\begin{array}{l}\text { Public works and } \\ \text { relief }\end{array} & 0.001648 & 1.91 & 0.93 & 0.88 & \text { volatility 3.68, area 3.94, church }-2.59 & \text { no } \\ \text { AAA } & & & & & & \\ & 0.002520 & 0.73 & 0.72 & 1.34 & \text { volatility }-0.21 \text {, area }-2.07 \text {, church } 0.62\end{array}$

\section{Panel C: 1933-1939}

Instruments include area, volatility, turnout, latitude, longitude, church 


$\begin{array}{lccccl}\begin{array}{l}\text { Public works and } \\ \text { relief } \\ \text { AAA }\end{array} & 0.000638 & 3.08 & 0.91 & 0.34 & \begin{array}{l}\text { volatility } 3.09, \text { turnout } 0.30, \text { area } 1.73, \\ \text { latitude } 0.60, \text { longitude } 0.64, \text { church }-3.19\end{array} \\ & 0.000005 & 0.03 & 0.01 & 0.00 & \begin{array}{l}\text { volatility }-0.45, \text { turnout } 2.04, \text { area }-0.95, \\ \text { latitude } 3.65, \text { longitude } 8.15, \text { church } 0.27\end{array}\end{array}$

Instruments include area, volatility, turnout, latitude, longitude

$\begin{array}{lllll}\text { Public works and } & 0.000507 & 1.96 & 2.13 & 0.27\end{array}$
relief

AAA

$\begin{array}{lll}0.000019 & 0.13 & -0.07\end{array}$

0.01

volatility 2.73 , turnout -0.18 , area 1.71 , latitude 0.65 , longitude 0.68

Instruments include volatility, turnout, latitude, longitude, church

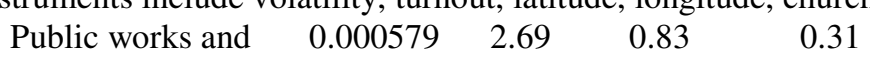

relief

AAA

$\begin{array}{lll}0.000022 & 0.14 & 0.03\end{array}$

0.01

volatility -0.42 , turnout 2.10 , area -0.95 , latitude 3.64 , longitude 8.15

Instruments include area, turnout, latitude, longitude, church

$\begin{array}{lllll}\text { Public works and } & 0.000803 & 2.61 & 1.15 & 0.43\end{array}$

relief

$\begin{array}{ccc}0.000803 & 2.61 & 1.15 \\ -0.00003 & -0.17 & -0.04\end{array}$

volatility 3.14 , turnout 0.15 , latitude 0.60 ,

longitude 0.65 , church -3.18

AAA

, volatility, turnout, church

$\begin{array}{ccr}\text { Instruments include area, volatility, turnout, church } \\ \text { Public works and } \quad 0.000665 \quad 2.91 & 0.95\end{array}$

relief

$0.000033 \quad 0.04 \quad 0.04$

$-0.02$

volatility -0.48 , turnout 2.12 , latitude

3.65 , longitude 8.14 , church 0.27

AAA

0.35

turnout -0.16 , area 1.82 , latitude 0.61 ,

longitude 0.85 , church -2.83

no

turnout 2.13 , area -0.97 , latitude 3.64 ,

longitude 8.13 , church 0.22

Instruments include area, volatility, latitude, longitude, church

$\begin{array}{lllll}\text { Public works and } & 0.000635 & 3.07 & 0.91 & 0.34\end{array}$

relief

$\begin{array}{lll}-0.00000 & -0.02 & 0.00\end{array}$

0.34

volatility 3.12 , turnout 0.26 , area 1.74 church -3.21

0.02 volatility -0.08 , turnout 1.73 , area -0.89 , church 0.10

AAA

0.00

volatility 3.08 , area 1.72 , latitude 0.59 , longitude 0.63 , church -3.18

no

Instruments include area, volatility, church

Public works and $\quad 0.000515 \quad 1.36$

0.74

volatility -0.75 , area -1.12 , latitude 3.55 ,

longitude 8.13 , church 0.58

relief

AAA

$\begin{array}{lll}-0.00117 & -0.51 \quad-1.50\end{array}$

0.27 volatility 3.11 , area 1.72 , church -3.21

no

Instruments include turnout, latitude, longitude

$\begin{array}{llll}\text { Public works and } & -0.00009 & -0.12 & 0.36\end{array}$

-0.62 volatility -0.33 , area -1.03 , church 0.36

relief

AAA

$0.000110 \quad 0.65 \quad 0.18$

-0.05 turnout -0.71 , latitude 0.65 , longitude 0.89

yes

Notes: The regressions underlying these results follow the basic specification reported in Table 3 . The area, turnout, volatility, latitude, longitude, and church variables are discussed in the text. "Invpop20" refers to the inverse of the 1920 population, "prdem32" was derived from a regression of the 1932 Democratic vote percentage on prior Democratic voting and state dummy variables, and mean9628 refer to the average percentage voting for the Democratic presidential candidate in the county from 1896 to 1928. See footnote 19.

A "no" answer in the column "Instruments Correlated with second-stage error?" indicates a failure to reject the hypothesis that the instrumental variables as a group are uncorrelated with the 2SLS estimate of the second-stage error term.

The impact on retail sales from a one dollar increase in per capita New Deal grant is calculated based on per capita retail sales of \$533.5 (1967\$), which was the average for 1939.

OSD refers to the number of standard deviations the dependent variable rises in response to a one-standard-deviation increase in the New Deal grants variable. 


\section{Appendix Table 4}

The Impact of New Deal Grants on the Change in Retail Sales: 1929-1939, 1929-1935, 1933-1939

\begin{tabular}{|c|c|c|c|c|c|}
\hline Specifications & Coeff. & $\begin{array}{l}\text { t- } \\
\text { stat. }\end{array}$ & $\begin{array}{l}\text { OSD } \\
\text { impact }\end{array}$ & $\begin{array}{l}\text { Impact on } \\
\text { retail sales } \\
\text { from one } \\
\text { dollar } \\
\text { increase in } \\
\text { New Deal } \\
\text { spending }\end{array}$ & $\begin{array}{l}\text { t-statistics of instruments } \\
\text { in first-stage }\end{array}$ \\
\hline
\end{tabular}

Panel A: 1929-1939

OLS, only New Deal as correlates

Public works and

relief

$0.03913 \quad 5.69$

$0.10 \quad 0.04$

AAA

$-0.16835 \quad-21.6$

$-0.37$

$-0.17$

OLS, all correlates

Public works and

relief

$0.01998 \quad 2.88$

0.05

0.02

AAA

$-0.06339 \quad-6.07$

$-0.14$

$-0.06$

2SLS, all correlates

Public works and

relief

$\begin{array}{lll}0.368009 & 3.25 & 0.90\end{array}$

0.37

volatility 3.02 , turnout 0.35 , area 1.78 , latitude 0.62 , longitude 0.81 , church -2.95
AAA
$-0.07965 \quad-0.92$
$-0.17$
$-0.08$ volatility -0.25 , turnout 1.83 , area -1.26 , latitude 3.66 , longitude 7.97 , church -0.02

Panel B: 1929-1935

OLS, only New Deal as correlates

Public works and relief

$\begin{array}{ll}0.03292 & 2.22\end{array}$

0.04

0.03

AAA

$-0.23074 \quad-13.8$

$-0.24$

$-0.23$

OLS, all correlates

Public works and

$\begin{array}{rrrr}0.03681 & 2.78 & 0.04 & 0.04 \\ -0.01157 & -0.59 & -0.01 & -0.01\end{array}$

relief

$-0.01$

2SLS (Instruments exclude latitude and longitude, which are included in the second-stage equation)

$0.39289 \quad 2.61 \quad 0.47$

relief

0.47

0.39

volatility 3.83 , turnout 1.31 ,

AAA

$\begin{array}{lll}-0.34219 & 0.81 \quad-0.36\end{array}$

-0.34 volatility 0.12 , turnout 2.31 , area -1.86 , church 0.28

Panel C: 1933-1939

OLS, only New Deal as correlates

Public works and

relief

$\begin{array}{ll}0.09337 & 11.79\end{array}$

0.23

0.09

AAA

$-0.00750 \quad-0.83$

$-0.02$

$-0.01$

OLS, all correlates

Public works and

relief

$0.000896 \quad 0.14$

0.00

0.00

AAA

$-0.02190 \quad-2.21$

$-0.05$

$-0.02$ 
2SLS, all correlates

Public works and

$\begin{array}{lll}0.32178 & 3.14 & 0.78\end{array}$

relief

AAA

0.00692

0.09

0.02

0.32 volatility 3.09 , turnout 0.30 , area 1.73 , latitude 0.60 , longitude 0.64 , church -3.19

0.01 volatility -0.45 , turnout 2.04 , area -0.95 , latitude 3.65 , longitude 8.15 , church 0.27

Notes: The dependent variable is the change in the level of retail sales per capita (in 1967\$) between the two years specified. Specifications with all correlates include the list of correlates and state dummies reported in Table 3 for 1929-1939. In the specification for 1929-1935, latitude and longitude are included in both the first and second stage equations. In the specification for 1933-1939 retail sales per capita in 1933 replaces retail sales per capita in 1929. The impact of a one dollar increase in per capita New Deal grants is the value of the coefficient.

The instruments are land area in square miles (area), the standard deviation of the percent voting Democrat for president from 1896 to 1928 (volatility), the number of votes cast in the 1928 presidential election divided by the population in 1930 (turnout), latitude, longitude, and church membership in 1926 as a percentage of the population in 1930 (church). 


\section{Appendix Table 5}

The Impact of the Natural Log of New Deal Grants on the Growth Rate in Retail Sales: 1929-1939, 1929-1935, 1933-1939

\begin{tabular}{|c|c|c|c|c|c|}
\hline Specification & Coeff. & $\begin{array}{l}\text { t- } \\
\text { stat. }\end{array}$ & $\begin{array}{l}\text { OSD } \\
\text { effect }\end{array}$ & $\begin{array}{l}\text { Impact } \\
\text { on retail } \\
\text { sales } \\
\text { from one } \\
\text { dollar } \\
\text { increase } \\
\text { in New } \\
\text { Deal } \\
\text { spending }\end{array}$ & $\begin{array}{l}\text { t-statistics of instruments in } \\
\text { first-stage }\end{array}$ \\
\hline
\end{tabular}

Panel A: 1929-1939

OLS, only New Deal as correlates

AAA

$\begin{array}{llll}-0.019520 & -2.75 & -0.05 & -0.04\end{array}$

$\begin{array}{llll}-0.038960 & -13.9 & -0.25 & -0.13\end{array}$

OLS, all correlates

$\begin{array}{lllll}\text { Public works and relief } & -0.001990 & -0.23 & -0.01 & 0.00\end{array}$

$\begin{array}{lllll}\text { AAA } & 0.009230 & 1.83 & 0.06 & 0.03\end{array}$

2SLS, all correlates

$\begin{array}{lllll}\text { Public works and relief } & 0.433223 & 1.35 & 1.11 & 0.88\end{array}$

volatility -0.50 , turnout -0.81 , area 0.73 , latitude 0.13 , longitude 1.10 , church -1.31
AAA
$-0.012760 \quad-0.33 \quad-0.08$
$-0.04$
volatility 2.10 , turnout -1.67 , area 3.45 , latitude 6.62 , longitude 7.02 , church 1.40

Panel B: 1929-1935

OLS, only New Deal as correlates

$\begin{array}{lllll}\text { Public works and relief } & -0.000289 & -0.04 & 0.00 & 0.00\end{array}$

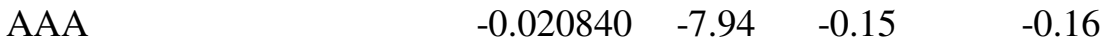

OLS, all correlates

Public works and relief $\quad-0.019830 \quad-2.32 \quad-0.05 \quad-0.11$

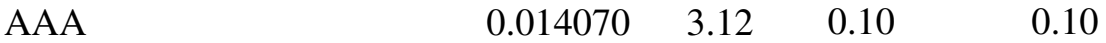

2SLS (Instruments exclude latitude and longitude, which are included in the second stage equation)

$\begin{array}{lllll}\text { Public works and relief } & 0.360170 & 1.68 & 0.90 & 2.02\end{array}$
AAA
0.140808
1.69
0.98
1.05

area 1.92 , church -2.04

Panel C: 1933-1939

OLS, only New Deal as correlates

Public works and relief

AAA

$\begin{array}{llll}0.00723 & 1.19 & 0.02 & 0.01\end{array}$

$\begin{array}{llll}-0.00096 & -0.40 & -0.01 & 0.00\end{array}$

OLS, all correlates

Public works and relief

AAA

$\begin{array}{llll}-0.0088 & -1.11 & -0.02 & -0.02\end{array}$

$\begin{array}{llll}0.00948 & 2.06 & 0.06 & 0.03\end{array}$

2SLS, all correlates 
Public works and relief $\quad 0.640699 \quad 1.73 \quad 1.63$

AAA

$-0.01947 \quad-0.41 \quad-0.12$
1.30 volatility -0.41 , turnout -0.87 , area 0.67 , latitude 0.19 , longitude 1.08 , church -1.47

-0.07 volatility 2.04 , turnout -1.34 , area 3.66, latitude 6.55 , longitude 6.75 , church 1.41

Notes: The dependent variable is the growth rate in per capita retail sales between the years specified. Specifications with all correlates include the logged value of the per capita New Deal variables, the logged value of the beginning retail sales per capita, and the remaining list of correlates reported in Table 3 . In the 1929-1935 specification latitude and longitude are added to the list of correlates in the secondstage stage. In the 1933-1939 specification the initial retail sales variable is from 1933. The impact of a one dollar increase in per capita New Deal grants assumes a base per capita retail sales of \$533.5 (1967 $\$$ ), which is the average for 1939. The calculation is (log of one plus the mean value of per capita grants) minus (the log of the mean per capita grant value) times the coefficient times $\$ 533.5$.

The instruments are land area in square miles (area), the standard deviation of the percent voting Democrat for president from 1896 to 1928 (volatility), the number of votes cast in the 1928 presidential election divided by the population in 1930 (turnout), latitude, longitude, and church membership in 1926 as a percentage of the population in 1930 (church). 


\section{Appendix Table 6}

Predicted Change in Retail Sales from \$1 of New Deal Spending Based on Various Assumptions

\begin{tabular}{|c|c|c|c|c|c|c|c|c|c|c|c|c|c|}
\hline Line & $\begin{array}{l}\text { EXTRA } \\
\text { INCOME IS } \\
\text { SPENT: }\end{array}$ & $t_{f}$ & $\mathbf{y}$ & $\mathbf{m}$ & $\begin{array}{l}\text { Base } \\
\text { Mult. } \\
\end{array}$ & C & $\mathbf{w}$ & b & $\mathbf{m}_{\mathrm{s}}$ & $\mathbf{m}_{\mathbf{n}}$ & $\mathbf{r}$ & $\begin{array}{l}\text { Income } \\
\text { Multiplie } \\
\mathbf{r} \\
\end{array}$ & $\begin{array}{l}\text { Change in } \\
\text { Retail } \\
\text { Sales from } \\
\$ 1 \text { of New } \\
\text { Deal } \\
\text { spending } \\
\end{array}$ \\
\hline & $\begin{array}{l}\text { 80 PERCENT } \\
\text { Relief and } \\
\text { Public Works }\end{array}$ & OCAL & & & & & & & & & & & \\
\hline 1 & Grants & 0.07 & 0.8 & 0.2 & 2.10 & -0.1 & 0.9 & 0 & 0.2 & 0.1 & 0.53 & 1.91 & 1.01 \\
\hline 2 & AAA Grant & 0.07 & 0.8 & 0.2 & 2.10 & 0 & 0.9 & -1 & 0.2 & 0 & 0.53 & 0.00 & 0.00 \\
\hline & $\begin{array}{l}\text { Relief and } \\
\text { Public Works } \\
\text { stimulate } \\
\text { private }\end{array}$ & & & & & & & & & & & & \\
\hline $1 \mathrm{a}$ & $\begin{array}{l}\text { production } \\
\text { Relief with } 50 \\
\text { Percent }\end{array}$ & 0.07 & 0.8 & 0.2 & 2.10 & -0.1 & 0.9 & 0.3 & 0.2 & 0.1 & 0.53 & 2.55 & 1.35 \\
\hline $1 b$ & $\begin{array}{l}\text { Crowding Out } \\
\text { AAA Grant } \\
\text { Harms Farm }\end{array}$ & 0.07 & 0.8 & 0.2 & 2.10 & -0.1 & 0.9 & -0.5 & 0.2 & 0.05 & 0.53 & 0.97 & 0.51 \\
\hline $2 a$ & Workers & 0.07 & 0.8 & 0.2 & 2.10 & 0 & 0.9 & -1.2 & 0.2 & 0 & 0.53 & -0.42 & -0.22 \\
\hline 3 & $\begin{array}{l}\text { 50 PERCENT } \\
\text { Public Works } \\
\text { and Relief } \\
\text { AAA Grant } \\
\text { Harms Farm }\end{array}$ & $\begin{array}{r}\text { OCAL } \\
0.07\end{array}$ & 0.5 & 0.5 & 0.93 & -0.1 & 0.9 & 0 & 0.2 & 0.1 & 0.53 & 0.85 & 0.45 \\
\hline 4 & Workers & 0.07 & 0.5 & 0.5 & 0.93 & 0 & 0.9 & -1.2 & 0.2 & 0 & 0.53 & -0.19 & -0.10 \\
\hline 5 & $\begin{array}{l}90 \text { PERCENT } \\
\text { Public Works } \\
\text { and Relief } \\
\text { AAA Grant } \\
\text { Harms Farm }\end{array}$ & $\begin{array}{r}\text { OCAL } \\
0.07\end{array}$ & 0.9 & 0.1 & 3.63 & -0.1 & 0.9 & 0 & 0.2 & 0.2 & 0.53 & 2.94 & 1.56 \\
\hline 6 & Workers & 0.07 & 0.9 & 0.1 & 3.63 & 0 & 0.9 & -1.2 & 0.2 & 0 & 0.53 & -0.73 & -0.39 \\
\hline
\end{tabular}

Legend:

$r$ is the ratio of retail sales to income.

Base mult. is the base multiplier.

$t_{f}$ is the federal income tax rate.

$y$ is the share of disposable income the populace spent on goods and services from inside the county.

$m$ is the share of disposable income the populace spent on goods and services from outside the county.

$c$ is the marginal effect of New Deal spending on state and local spending; flypaper effects imply $c>0$, while crowding out effects imply $\mathrm{c}<0$.

$w$ is the ratio of state and local taxes to state and local spending; deficit financing means $\mathrm{w}<1$.

$b$ is the impact of New Deal spending on private production for export. Positive externalities from social overhead capital imply a positive b. Replacement of production as with the AAA implies a negative $b$.

$m_{n}$ is the share of New Deal spending spent on goods and services from outside the county. 
$m_{s}$ is the share of state and local spending spent on goods and services from outside the county. $\mu$ is the income multiplier after all effects are factored in. 